\title{
High Performance Self-Consolidating Cementitious Composites
}

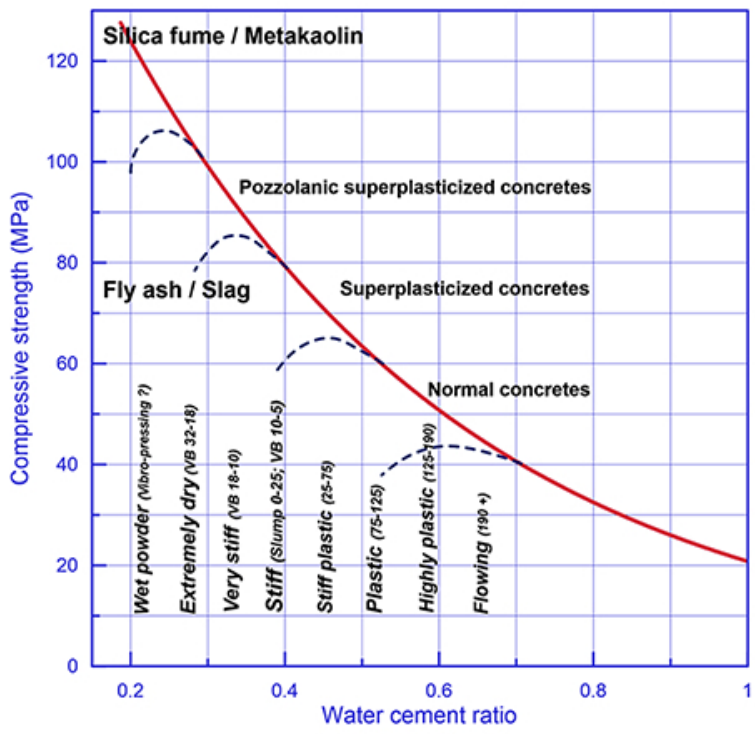

\section{Ganesh Babu Kodeboyina}

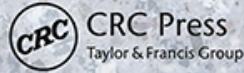




\section{High Performance Self-Consolidating \\ Cementitious Composites}


$\because$ Taylor \& Francis

Taylor \& Francis Group

http://taylorandfrancis.com 


\section{High Performance Self-Consolidating \\ Cementitious Composites}

Prof. Ganesh Babu Kodeboyina

Former Director, Central Building Research Institute (CSIR-CBRI), Roorkee and

Professor, Indian Institute of Technology Madras, Chennai.

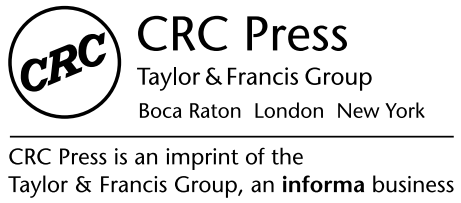


CRC Press

Taylor \& Francis Group

6000 Broken Sound Parkway NW, Suite 300

Boca Raton, FL 33487-2742

(C) 2018 by Taylor \& Francis Group, LLC

CRC Press is an imprint of Taylor \& Francis Group, an Informa business

No claim to original U.S. Government works

Printed on acid-free paper

International Standard Book Number-13: 978-1-138-06304-4 (Hardback)

This book contains information obtained from authentic and highly regarded sources. Reasonable efforts have been made to publish reliable data and information, but the author and publisher cannot assume responsibility for the validity of all materials or the consequences of their use. The authors and publishers have attempted to trace the copyright holders of all material reproduced in this publication and apologize to copyright holders if permission to publish in this form has not been obtained. If any copyright material has not been acknowledged please write and let us know so we may rectify in any future reprint.

Except as permitted under U.S. Copyright Law, no part of this book may be reprinted, reproduced, transmitted, or utilized in any form by any electronic, mechanical, or other means, now known or hereafter invented, including photocopying, microfilming, and recording, or in any information storage or retrieval system, without written permission from the publishers.

For permission to photocopy or use material electronically from this work, please access www. copyright.com (http:/ / www.copyright.com/) or contact the Copyright Clearance Center, Inc. (CCC), 222 Rosewood Drive, Danvers, MA 01923, 978-750-8400. CCC is a not-for-profit organization that provides licenses and registration for a variety of users. For organizations that have been granted a photocopy license by the CCC, a separate system of payment has been arranged.

Trademark Notice: Product or corporate names may be trademarks or registered trademarks, and are used only for identification and explanation without intent to infringe.

Library of Congress Cataloging-in-Publication Data

Names: Kodeboyina, Ganesh Babu, author.

Title: High performance self-consolidating cementitious composites / Ganesh

Babu Kodeboyina.

Description: Boca Raton : Taylor \& Francis, a CRC title, part of the Taylor \& Francis imprint, a member of the Taylor \& Francis Group, the academic division of T\&F Informa, plc, 2018. | Includes bibliographical references and index.

Identifiers: LCCN 2017042109 | ISBN 9781138063044 (hardback : acid-free paper)

| ISBN 9781315161310 (ebook)

Subjects: LCSH: Cement composites.

Classification: LCC TA438 .K63 2018 | DDC 620.1/35--dc23

LC record available at https://lccn.loc.gov/2017042109

Visit the Taylor \& Francis Web site at
http://www.taylorandfrancis.com

and the CRC Press Web site at

http://www.crcpress.com 


\section{Contents}

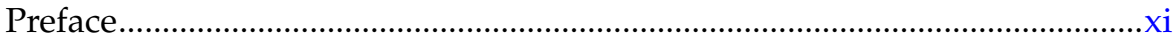

Acknowledgments ...................................................................................... xiii

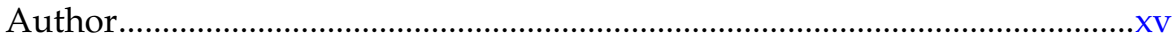

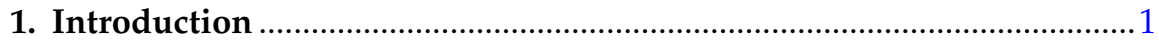

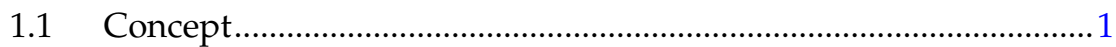

1.2 Historical Development ..................................................................

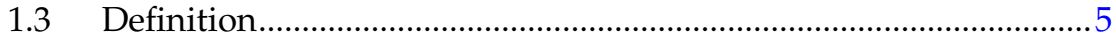

1.4 Formulations and Classifications of SCCs........................................

1.5 Potential and Limitations............................................................... 8

1.6 Future Prospects ..........................................................................

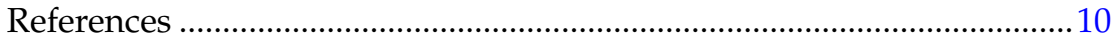

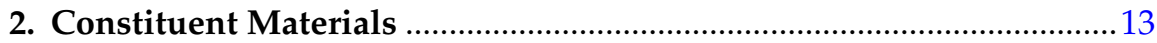

2.1 Constituent Materials and Availability …….....................................13

2.2 Cements and Characteristics ………………..................................14

2.3 Simple Powder Extenders................................................................17

2.4 Supplementary Cementitious Materials ...........................................18

2.4.1 Pulverized Fuel Ash or Fly Ash ..........................................19

2.4.2 Ground Granulated Blast Furnace Slag................................21

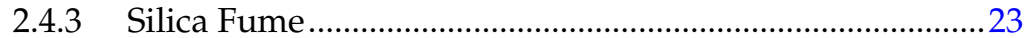

2.4.4 Other Pozzolanic Admixtures ................................................23

2.5 Superplasticizers and Other Chemical Admixtures.........................26

2.5.1 Superplasticizers or High-Range Water Reducing

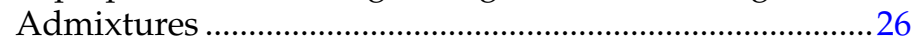

2.5.2 Viscosity Modifying Admixtures........................................22

2.5.3 Other Admixtures ................................................................27

2.5.4 Mixing Water ...................................................................... 27

$2.6 \quad$ Aggregate Characteristics ................................................................28

2.6.1 Reinforcing Fibers ..................................................................34

2.7 Interactions and Compatibility ……………….................................35

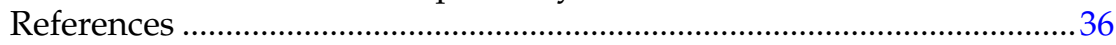

3. Insights into Standards and Specifications ……………..........................39

3.1 Standardization Principles....................................................................39

3.2 Fundamental Characterization and Classification ............................40

3.3 Methods of Consistency Measurement............................................4 42

3.3.1 Slump Flow and $\mathrm{T}_{500}$ Tests ..................................................45

3.3.2 J-Ring Test ............................................................................ 48

3.3.3 V-Funnel Test ......................................................................50 


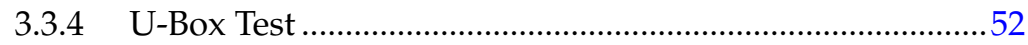

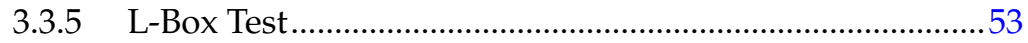

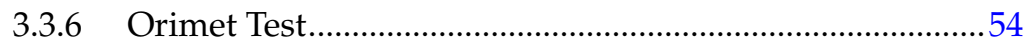

3.3.7 Mesh Box Test.....................................................................55

3.3.8 Fill Box (Kajima Box) Test ....................................................55

3.3.9 Screen Stability Test ................................................................56

3.3.10 Column Settlement Test ..........................................................57

3.3.11 Penetration Resistance Test ...............................................58

3.3.12 Job Site Acceptance Methods ..............................................58

$3.4 \quad$ Japanese Recommendations ...........................................................59

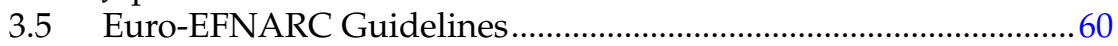

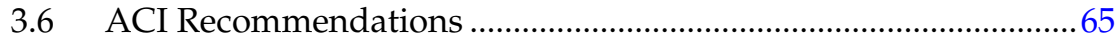

3.7 Other Perceptions..............................................................................6

3.8 Summary and Suggestions ............................................................69

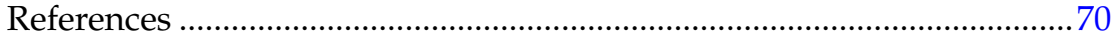

4. Methodologies for the Proportioning of SCC Mixtures ........................73

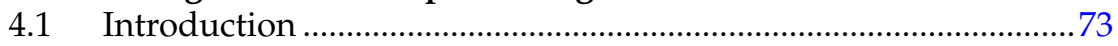

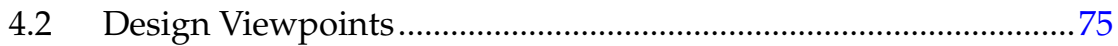

4.3 Semi-empirical Methods ..................................................................... 81

4.4 Compositions Based on Wetting Water Requirements of the Constituents ................................................................................... 85

4.5 Methods Based on Aggregate Distribution and Packing Factors

4.6 Methods of Limiting the Cementitious Materials through Water Content...................................................................................... 91

4.7 Methods of Incorporating the Cementitious Efficiency

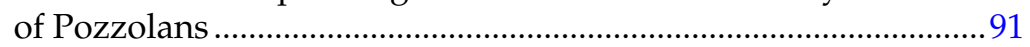

4.8 Procedures for Incorporating Different Pozzolans .........................92

4.9 Approaches for a Specified Compressive Strength ..........................95

4.10 Methods Based on Rheometer Tests ....................................................97

4.11 Methods Based on the Rheological Paste Model..............................97

4.12 Methods Based on the Rheological Paste Model Incorporating Fibrous Materials ....................................................99

4.13 Guidelines Based on Statistical Evaluations ………………….........100

4.14 Need for a Relook and Proposed Methodology ..............................102

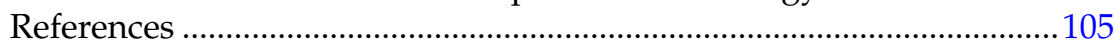

5. Concepts and Criteria for High-Performance Self-Compacting Concretes

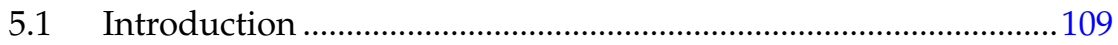

5.2 Fundamental Concepts of Performance ........................................ 110

5.3 Environmental Parameters ................................................................. 111 
5.4 Practical Approach for High-Performance Design ........................ 116

5.4.1 Concrete Production Practice ............................................... 117

5.5 Performance Evaluation Methodologies ........................................ 118

5.6 Concept of Pozzolanic Efficiency and Strength Relations ........... 118

5.6.1 Efficiency Concept .............................................................. 119

5.6.2 Evaluation of Efficiency …………………..........................122

5.6.3 Factors Influencing the Efficiency of Fly Ash ...................130

5.6.4 Water-Cement Ratio to the Strength Relation...................135

5.7 Effects of Pozzolanic Addition on Consistency …….......................141

5.8 Packing and Optimal Granular Skeleton........................................142

5.9 Proposed Methodology for High-Performance SCCs .................. 144

5.9.1 Strength Assessment of the Pozzolanic Cementitious

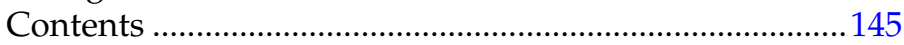

5.9.2 Water Content, Plasticizer, and VMA Interactions...........146

5.9.3 Aggregate Grading and Proportioning on the Packing and Loosening Aspects ...........................................148

5.9.4 Optimal Utilization of Pozzolanic Materials for High-Performance SCCs

5.10 Efficacy of the Proposed Methodology ………..............................153

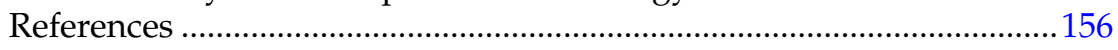

6. SCCs Based on Powder Extenders and Low-End Pozzolans...............159

6.1 Introduction ................................................................................ 159

6.2 Concept of Powder Extenders.........................................................160

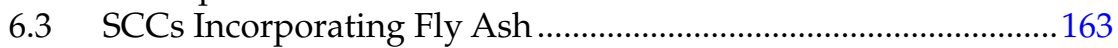

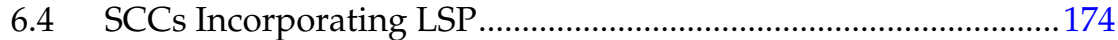

6.5 SCCs Incorporating GGBS ............................................................179

6.6 SCCs through Other Inert Powder Extenders ................................. 181

6.7 Practical Limitations on Powder Fillers ..........................................183

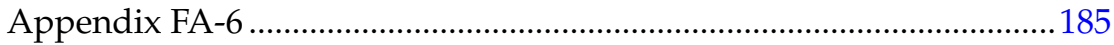

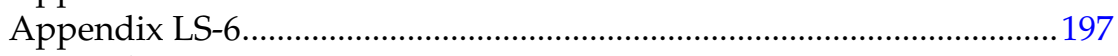

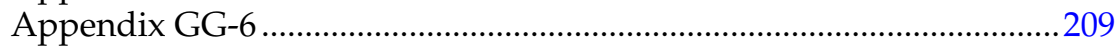

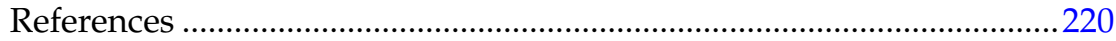

7. SCCs Based on High Efficiency and Nano Pozzolans …………….......227

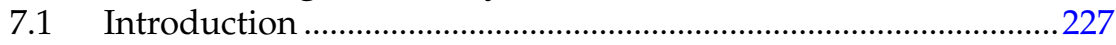

7.2 Concepts of High Strength and High Performance .....................228

7.3 SCCs Incorporating Silica Fume and Nanosilica.............................229

7.3.1 SCCs Incorporating Silica Fume ..........................................2232

7.3.2 Evaluation of Efficiency of Silica Fume ……….................2233

7.3.3 SCCs with Nanosilica.........................................................245

$7.4 \quad$ SCCs Incorporating Calcined Clays ..................................................24

7.5 SCCs Incorporating Rice Husk Ash ……………………………......249 
7.6 Saturation Concepts and Effects ..................................................2252

7.7 SCCs Incorporating Fibrous Constituents.......................................254

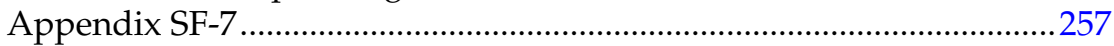

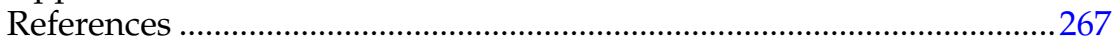

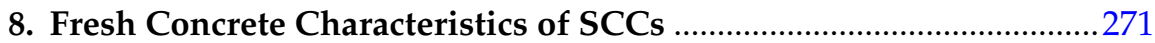

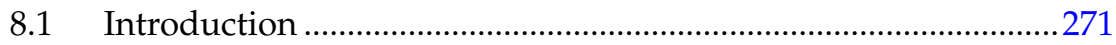

8.2 Fundamentals of Consistency and Compaction............................2272

8.3 Rheology and Thixotropy of SCCs ……………………………......2. 274

8.4 Critical Evaluation and Comparison of the Test Methods ...........276

8.5 Effects of Quality and Quantity of Cementitious Materials .......299

8.6 Wetting Water Requirements of Powder Materials.........................301

8.6.1 Superplasticizer Requirements of Pozzolanic

Cementitious Mixtures..............................................................303

8.6.2 Effect of Pozzolanic Admixtures on Setting Times ..........305

8.6.3 Effect of Pozzolanic Admixtures on Strength Characteristics …………......................................................306

8.6.4 Effect of Superplasticizer on the Water Requirement of Pozzolanic Cementitious Mixtures ..................................309

8.7 Effects of Granular Skeleton Characteristics and Fibrous

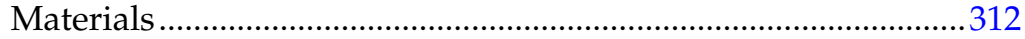

8.8 Segregation and Bleeding .................................................................313

8.9 Shrinkage and Heat of Hydration ........................................................314

8.10 Transport, Placement, and Finishing.................................................315

8.11 Formwork and Pressure on Formwork..............................................316

8.12 Setting Times and Removal of Forms ..........................................317

8.13 Curing Needs, Precautions, and Best Practices ...............................318

8.14 Effect of Accelerated Curing and Maturity Concepts....................319

8.15 Quality Assurance and Control ..........................................................321

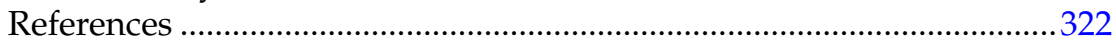

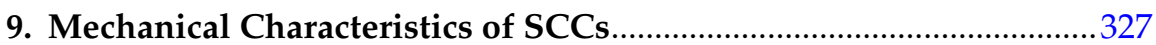

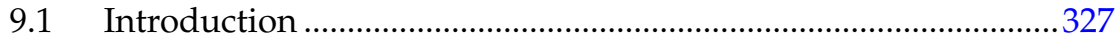

9.2 Physical Properties and Microstructural Effects.............................327

9.3 Compressive Strength and Strength Gain Rate .............................345

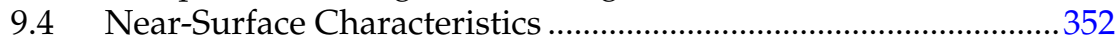

9.5 Tensile and Shear Strengths..............................................................354

9.6 Applicability of Conventional Concrete Relations to SCCs.........355

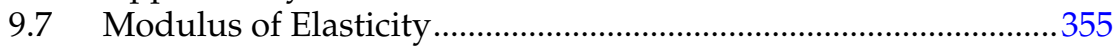

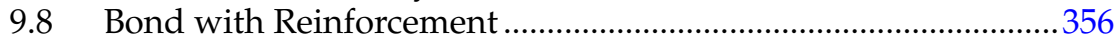

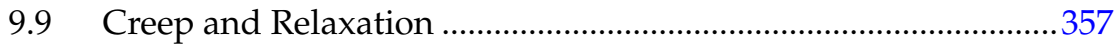

9.10 Prestressing and Anchorages .........................................................357

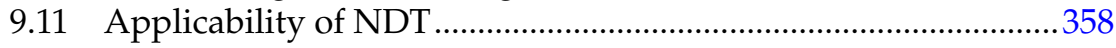

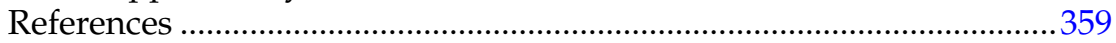


10. Performance and Service Life of Self-Compacting Concrete...............365

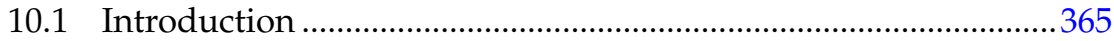

10.2 Durability of Concrete .........................................................................366

10.2.1 Environmental Parameters ................................................367

10.2.2 Concrete Parameters...........................................................369

10.2.2.1 Alkalinity of Concrete............................................369

10.2.2.2 Resistivity of Concrete...........................................370

10.2.3 Reinforcement Parameters....................................................370

10.2.3.1 Tests Related to Concrete .....................................370

10.2.3.2 Tests Related to Steel Reinforcement..................373

10.2.4 Methods of Corrosion Control .............................................374

10.2.5 Durability Investigations ....................................................376

10.3 Strength and Porosity ………………………..................................380

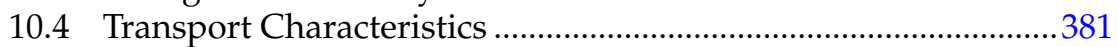

10.5 Environmental Degradation ........................................................387

10.6 Chemical Degradation........................................................................389

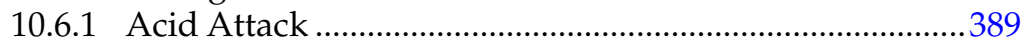

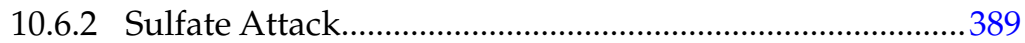

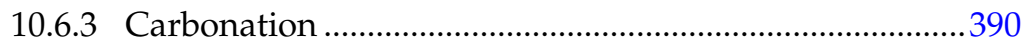

10.7 Alkali-Aggregate Reactivity..............................................................391

10.8 Thermal Degradation ..........................................................................391

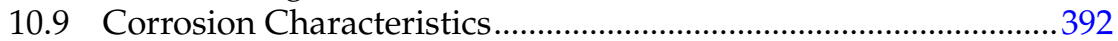

10.10 Service-Life Prediction or Residual Life Evaluation Methods ...395

10.10.1 Chloride Diffusivity............................................................396

10.10.2 Macrocell Corrosion Test ……………………......................397

10.10.3 Thermal Cycling of Concrete ...............................................398

10.10.4 Service-Life Determination Using Chloride Diffusivity.... 399

10.10.5 Chloride Diffusion Studies .....................................................403

10.10.6 Corrosion Rate Studies..........................................................403

10.10.7 Electrolytic Accelerated Corrosion Studies.........................404

10.10.8 Service-Life Determination Using Carbonation ................. 407

10.10.9 Service-Life Management of Constructed Facilities ........ 408

References 409

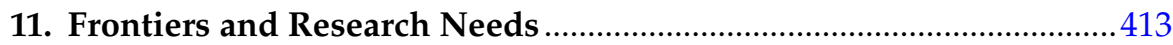

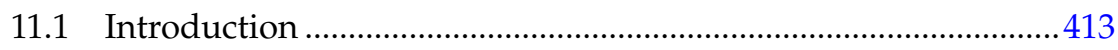

11.2 Applications and Prospects ............................................................414

11.3 SCCs in Repair and Rehabilitation Practice ....................................416

11.4 Re-Alkalization of Concrete............................................................417

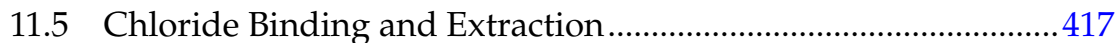

11.6 Tunnel Lining and Grouting Applications ......................................418

11.7 Underwater Concrete Applications and Repair ..............................418

11.8 Applications in Marine Environment .............................................419

11.9 Ultra-High-Strength Grouts and Composites..................................419 
11.10 Reinforced Fibrous Composites ......................................................420

11.11 Research and Developmental Requirements ..................................422

11.12 Concluding Remarks .....................................................................422

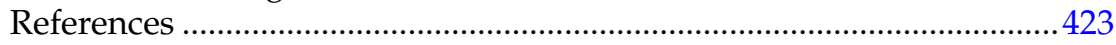

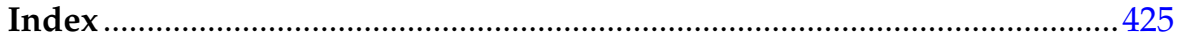




\section{Preface}

The improving urbanization standards forced the construction industry to look for not only the most economical of the construction materials but also avenues to ensure high performance, necessitating a significant transformation in its outlook. Self-consolidating concretes brought about a lasting change in the construction setup, even if it was only by tweaking some of the existing materials, design, and production methodologies already well known to the industry.

High Performance Self-Consolidating Cementitious Composites attempts to bring together some of the basic intricacies in the production of the complete range of self-consolidating cementitious composites, with a proper understanding of the contributions of different materials and their combinations. To the discerning reader the two fundamentals aspects - the modulation of rheology of cementitious materials paste through superplasticizers and viscosity-modifying agents, and the interaction of this paste phase with filler components like coarse and fine aggregates - to ensure a self-compacting mass are explained. Also, it was presumed a priori that given the higher fines content and the self-compactability for ensuring a defect-free structure and recognizing the fact that additional fines are generally supplemented through materials like fly ash, the resulting concrete will automatically be of high performance. However, there is a need to understand the pore filling and pozzolanic effects of the powders and the different supplementary cementitious materials in vogue appropriately, to ensure that both the strength and the performance could be adequately predicted, which is also explained in detail herein.

Another important factor that is probably not fairly conspicuous and is often overlooked is that with the limited budgetary provisions available for most research efforts, even in prestigious research laboratories and educational institutions, coupled with the limited time and manpower available, studies in general are limited to specific targets in each case. An overarching program of research, like the "Concrete in the Oceans" program of the United Kingdom, will need support for over a decade with several specific aspects looked at by different institutes to ensure a realistic and comprehensive understanding. However, there are a lot of efforts directed toward different goals by several members of the research community. Now, the other way to find a solution for this problem was to comprehensively put together these diverse research efforts of the different investigators, identify the broad fundamentals underlying the different aspects of the problem, and systematically analyze the information to arrive at a more holistic understanding. This approach, more easily said than done, needs a compilation of the available results into a data platform; it also needs categorization of the results 
under acceptable scientific criteria through earlier experience, and finally we can arrive at broad guidelines for an appropriate understanding of the problem. In line with this, an effort was made in this book to compile a large database on self-compacting concretes from the literature, categorize them to represent specific groups, and suggest methods for arriving at self-compacting concretes with a wide range of materials and over a wide range of consistencies. Apart from this, High Performance Self-Consolidating Cementitious Composites tries to look at the performance and limitations of this regime of concretes and suggests methods to address some of these appropriately. Naturally, in some cases a few of the aspects discussed were based only on the limited information available from the earlier investigations and may have to be verified before extending them to reflect the behavior of the entire spectrum of self-compacting concretes.

The fact that it is not possible to summarize even partly the volume of information available from various conferences, seminars, and publications available on a topic that has generated an enormous amount of interest in the research and development community as well as the construction industry was well recognized. Naturally, the basic idea was to only highlight the critical parameters and interactions between these parameters to ensure the production of high-performance, self-consolidating cementitious composites with greater confidence. The second aspect was to collate a relevant group of concretes in each particular case and put together a series of ready reckoner charts to have a guideline for arriving at an appropriate self-consolidating cementitious composite of choice. Finally, it was attempted to present briefly the relationships between various green and hardened state characteristics. High Performance Self-Consolidating Cementitious Composites also presents a broad outline of the present state of the art, in terms of the different national recommendations and codal provisions, the views and perceptions of the industry, along with an insight into the basic materials technology. Specifically, some of the graphs (nomograms) could help the practicing engineers on-site to understand and modulate the concrete composites being produced directly. Thus, instead of summarizing the information available in literature, the book envisages to be a tool for explaining the basic relationships and the interactions between the constituents to assist students, researchers, and industry professionals. 


\section{Acknowledgments}

Self-consolidating concrete has attracted the attention of both the industry and the research community because of the ease of placement and time saved in concreting operations. Naturally, this prompted several efforts toward the design, production, and placement of the material. A critical and explicit understanding of the insights into any such concrete requires understanding of the contributions from several earlier researchers on the various facets that originally resulted in the development of the high-performance cementitious composites of today. I heavily relied on the wealth of knowledge that originated from North America and, more importantly, Europe in the attempts to present the topic in my own perspective. Many of the concepts that are discussed and elaborated in these pages have in the background the several discussions I had with these researchers, teachers, and students, even if some of them were not directly related to the making of this book.

At the very outset, I should thank profusely all my teachers starting from school to the point of obtaining my doctorate as well as several other professional colleagues who always encouraged me in my efforts to just learn. It is only appropriate to acknowledge the fact that among several of these tall figures is the name of one distinguished personality that stands out, Prof. Dr.-Ing. P. Srinivasa Rao, Department of Civil Engineering, Indian Institute of Technology, Madras, who inculcated in me an intensely critical thinking, strict attention to detail, and persistence, being a guide and mentor during my time as his research student for my master's and doctoral programs and also later as his associate at the institute.

I also gratefully acknowledge that it was indeed an honor to be a fellow of the Alexander von Humboldt Foundation, which helped me to not only interact with several eminent professors and researchers from German universities but also helped me in learning the German language so that I can have a direct understanding of the literature published, apart from being a member of their research and social community. Some of the specific intricacies in the modifications of concrete are hidden in the earlier literature that was largely published in German, and for an individual educated in the English medium, there is limited possibility of getting to know them. During a later visit as an Indo-German fellow, I had the opportunity to be associated with Prof. Dr.-Ing. Peter Schiessl, then heading the Institut für Bauforschung, RWTH Aachen University, Aachen, working on fly ash and corrosion of steel in concrete. It was indeed this association that paved the way for the development of the concept of dual factors in cementitious efficiency of most pozzolanic admixtures, which forms the central theme of this book. I thank him with all my heart for all the long and open discussions on the several aspects of fly ash in concrete and also corrosion of steel in concrete. 
Also, over the years, it was indeed a pleasure to be associated with a very large number of students, who during their research efforts inadvertently posed several questions that needed to be answered. They also participated in many ways in refining and reorienting probably some of the known facts to be put in their proper perspective. Even among this very large group of well over a hundred, I should specifically appreciate and thank the efforts of Bhojaraju ESTR Chandrasekhar, a PhD scholar, particularly for his contribution in shaping this book in the present form through his several unending objective discussions and also, more importantly, through his untiring efforts to help in processing and producing most of the graphs and nomograms into the present form that really make them stand out as the hallmark of this book.

Finally and most importantly, I express my deep sense of gratitude to my family, my wife Devi, daughter Deepti, and son Srikanth Aditya, for their love and understanding of my absence during the several academic and professional commitments over the years. 


\section{Author}

Professor Ganesh Babu Kodeboyina obtained his bachelor's degree in civil engineering with distinction from the Andhra University and joined the Indian Institute of Technology (IIT) Madras for a master's degree in structural engineering. He continued at IIT Madras and obtained a doctoral degree, working in the area of behavior of partially prestressed concrete structural members. He then joined Structural Engineering Research Centre as a scientist and was involved in several projects including large diameter prestressed concrete pipes, ferro cement and fiber reinforced concrete, apart from being the principal investigator on the United Nations Development Programme (UNDP)-sponsored project on Polymer Concrete Composites. He was awarded the Alexander von Humboldt $(\mathrm{AvH})$ Foundation Fellowship during this period to undertake postdoctoral research in Germany.

However, during the same period, he joined IIT Madras as a faculty member of the Department of Ocean Engineering, working in the area of ocean structures and materials in marine environment, and undertook his $\mathrm{AvH}$ fellowship program. After his return to Germany even while he was engaged in active research on offshore structures, with special interest, he singlehandedly developed the most successful "Structures, Materials, Applications and Rehabilitation Technologies" laboratory of the department, which he headed until retirement. Apart from being an active research worker producing more than 20 doctoral theses, and several other master's theses on the various topics related to ocean structures, and in particular on materials in marine environment, he was also a consultant to the industry on several different aspects. To mention a few, as a structural engineer, he proof-checked designs of more than 50 prestressed concrete bridges and suggested the repair strategies for another 100 bridges of the National Highway Authority of India, designed and rehabilitated several port and harbor facilities apart from damage assessment, and was involved in the rehabilitation of a large number of operating industrial structures. Even so, he was better known for his contributions to high-performance cementitious composites and was a retainer consultant to nearly all the major cement producers as well as construction chemical manufacturers in the country. In fact, he investigated the performance characteristics of almost all of the cements that were produced by these industries. Apart from this, he was a part of the UN common fundsponsored program, and was entrusted with the evaluation of the corrosion performance of galvanized reinforcement both in the laboratory and at the Madras port field site organized by him exclusively for this purpose.

These achievements resulted in him being appointed as the director of the Central Building Research Institute (CBRI), Roorkee, a prestigious constituent 
National Laboratory of the Council of Scientific and Industrial Research (CSIR) of the Government of India. It was here that, apart from other research activities as director, he undertook several rehabilitation projects, notably the rehabilitation of the only existing double shell built by the famous Prof. Kurt Billig, the very first director of the CSIR-CBRI. These efforts culminated in his being involved in several activities related to the preservation and rehabilitation of many of the centuries-old temples and also other world heritage sites in the country like the Taj Mahal, Konark, and many others, an activity close to his heart, or his premier passion.

He later returned to IIT Madras to complete his tenure at the institute and was once again involved in research and consultancy in areas of ternary cements, Ultra-High-Performance Concretes (UHPCs), and polymer composites. He also undertook a study on the residual service life and service-life extension measures of the Fast Breeder Test Reactor (FBTR). Incidentally, he was responsible for the design and testing of thermal effects on heavyweight concretes that had to be almost self-consolidating in the enclosed top shield of the Prototype Fast Breeder Reactor (PFBR). He was rated a very good teacher by several groups of students and is also passionate about fine arts, ancient texts on yoga, and temple vastu, to name a few. 


\section{1}

\section{Introduction}

\subsection{Concept}

Concrete has been the preferred material for construction because it can be molded into any shape dictated by the structural configuration requirements while being the most economical. Cementitious composites have undergone several changes over the years, due to the advancements in cement production processes resulting in higher-grade cements and the advent of modern pozzolanic and chemical admixtures, leading to strengths reaching the levels of steel in compression, while having significantly improved performance characteristics even in the most aggressive of environments. However, being a highly complex composite with so many materials of varying sizes, shapes, and textures, the prediction of the strength and performance of the resultant material has always been a matter of serious concern, without stringent control on the constitutes. The large and ever expanding database of research findings with several different local constituents, be it aggregates or the cements produced or the admixtures utilized in these concrete composites, also causes a certain amount of confusion in understanding the material.

In the context of the normally vibrated concretes, be it the general-purpose concretes, high-strength concretes, no slump concretes, or even lightweight concretes, recommendations are available for arriving at a concrete of a specific strength and consistency required for a particular application in the construction activity. In brief, the methodology adopted was to define the water-cement ratio in terms of the strength required for the structural member. Depending on parameters such as the construction practice, member size, and dimensions, the consistency or the workability of concrete was fixed. The workability ranges from no slump to a collapse slump based on the compaction procedures adopted. Depending on the constituent materials, particularly the maximum size of the aggregate, the water content is defined for that workability. After this the coarse aggregate and fine aggregate proportions are fixed or a continuously graded aggregate is recommended for each maximum size of the aggregate. All these were possible through an understanding of the gradation of aggregates and the amount 
of paste and mortar contents including water, which were all chosen from a very large database of the experimental evaluations and field experiences that are available on these types of normally vibrated concrete systems. One important factor that was also learned during these investigations was that an inadequate compaction of the resulting mass can significantly affect the strength of the composite ultimately. Several compaction procedures such as vibro-compaction, high-frequency vibration, vacuum dewatering, spinning, and pressure application have all been used effectively, depending upon the member details and construction practices available. Naturally, the emphasis is more on appropriate concrete compaction methodologies to alleviate the problems associated with the lowering of strengths during these processes. Though the most desired parameter in defining the characteristics of concrete is strength, which is related to the water to cement ratio, the fact that it can be produced with various workabilities at different water contents was also well established. Slump is a measure of the workability, and structural concretes with no slump to collapse slump characteristics can be produced in practice with water contents ranging from 150 to $215 \mathrm{~kg} / \mathrm{m}^{3}$, as recommended in the ACI guidelines (ACI 211.1, 1997).

In this complex scenario wherein the concrete has undergone several significant modifications to cater to the varying needs of the construction industry, the modification that has attracted the attention of the industry in recent times is the concept of self-compacting or self-consolidating concrete (SCC), a concrete that consolidates under its own weight. This concept of SCC, originally articulated by Okamura (1995), came into existence in an effort to design a concrete mix that could consolidate and fill without any difficulty the massive end anchorages of the Akashi-Kaikyo bridge with its highly impenetrable surface reinforcement cage and anchorage details. These SCCs have also been referred to in the literature as SCCs, self-placing concretes, and self-levelling concretes by a few, depending upon the requirements and perception. Semioli (2001) opines that a less dramatic terminology such as self-accommodating concrete might be more appropriate to describe the self-levelling and selfcompacting properties that permit easier installation and working at sites for Lafarge's "Agilia," which was termed a self-placing concrete by them. He also discussed its use for both horizontal and vertical applications as well as in the repair and rehabilitation of an old courthouse structure. Szecsy (2002) presented a broad discussion on the nomenclature as well as the technology. He opines that each of these different names defines a specific aspect of the type of concrete, namely, SCC - a concrete that consolidates through gravity to achieve maximum density without the need for vibration, self-levelling concrete (SLC) - a concrete that can seek a level grade within the formwork, and self-placing concrete (SPC) - a concrete that has ease of placement and has the ability to be both self-compacting and self-levelling. The various admixtures that help in achieving self-compactability (mostly polycarboxylate-based superplasticizers in recent years) and a few tests that establish the different workability characteristics have also been presented. Also, others followed 
a similar approach in defining what is expected of SCC over the years. To be more specific the name carries the entire meaning of the expectation from the cementitious composites developed.

\subsection{Historical Development}

One of the significant developments in the area of concrete technology could be traced to the advent of superplasticizers, though certain classes of plasticizers have always been available from times immemorial, even from the early lime concrete technology periods. This change is essentially because concretes with even a limited slump of just $25-50 \mathrm{~mm}$ could be readily reduced to a fluid consistency with collapse slump, if only it is ensured that there is enough sand and fines (even cement as in the case of high-strength concretes of lower water-cement ratio) in the mix. The simple yet often forgotten rule in the development of these concretes was to increase the sand content by about $10 \%$ and also to have a good gradation in the coarse aggregate fractions. These are then termed as superplasticized concretes; while the same superplasticizers could be utilized in concretes where the slump was nearly retained at the original level of $25-50 \mathrm{~mm}$ by appropriately reducing the water content (almost by about $20 \%$ if possible) and be termed as highrange water reducing admixtures, resulting in significantly higher strengths in these concretes. This in a way promoted the initial development of highstrength concretes, which were presumed, even if wrongly, to be an approach for realizing high-performance concretes due to their lower water-cement ratio and the resultant discontinuous capillary pore structure that could inhibit the permeation of moisture and environment.

The second significant development in concrete technology is the introduction of silica fume (an industrial waste from the ferrosilicon industry) as a pozzolan and the consequent development of very high-strength highperformance concretes. Simultaneously a lot of interest was generated in the use of secondary cementitious materials or mineral admixtures, which not only ensure a saving of cement and economy but also impart a higher performance. The need for an effective utilization of the abundantly available industrial wastes like fly ash from thermal power stations as an industrial waste and slag from steel plants (in the form of ground granulated blast furnace slag, GGBS) also contributed to the formulation of binary cement composites. These pozzolans in conjunction with the available superplasticizers paved the way for an entirely new regime of concrete and concrete composites that proved to be of a significantly higher performance with the possibility of also achieving very high strengths. Many other materials such as metakaolin, zeolite, and rice husk ash (RHA) have also come to be used as pozzolanic materials. 
SCCs have essentially evolved in the background of these significant changes that took place in the past few decades. Okamura published a few studies prior to his proposed mix design methodology for SCCs leading to its use in the end anchorages of the Akashi-Kaikyo bridge (Okamura, 1994, $1995,2003)$. The method, simply stated, attempted to achieve a highly workable and thixotropic mix through augmented fines and superplasticizers while reducing the coarse aggregate content. After this initial semi-empirical approach of modifying the conventional concrete design, researchers appear to have looked for avenues to achieve self-compactability though several different approaches, which are later, delineated. It looks obvious that the primary objective of any design methodology proposed to date is to achieve a cohesive and stable SCC without much thought given to its strength or performance characteristics.

A closer look at the broad spectrum of concrete composites will clearly show that SCCs, considered to be new in the present day context, are not in any way totally unknown to the industry. Several references could be found to concretes of collapse slump, sometimes termed as flowing concretes, self-levelling concretes, and grouts that exhibit slumps of 200-250 $\mathrm{mm}$ and even beyond, which were formulated to have no bleeding and segregation either through manipulations in cement content or by using thixotropy-imparting agents like vinyl- or cellulose-based materials. These were far more common as concrete composites suitable for underwater application with the necessary anti-washout characteristics even in the continuous or oscillatory flow regimes occurring in river, estuarine, or ocean environments (Gerwick, 2015). Some such precursors to SCCs have been described by Collepardi $(2001,2005,2007)$. Apart from these facts, spatiality grouts of self-levelling nature have been in the market for quite some time now, and in applications requiring higher thickness of concrete for repair and rehabilitation these have been used incorporating $50 \%-60 \%$ well-graded coarse aggregate of a maximum size up to $10-12 \mathrm{~mm}$. Such concretes were also developed in the laboratory for applications such as jacketing repairs of corroded columns and beams in both industrial and marine structures.

Some other aspects that are often quoted as factors that distinguish an SCC from a normally vibrated concrete (NVC) are the use of fly ash (maybe up to about $30 \%-40 \%$ of the total cementitious material or sometimes other fine materials as powder extenders) and a viscosity modifying agent (VMA). However, concretes with supplementary cementitious materials like fly ash, particularly to ensure reasonable economy in the normal strength concrete production, are well known. It is also known that to control the increased wetting water requirements of the increased surface area due to the presence of these powder extenders superplasticizers are often the only solution unless the total cementitious materials are kept well within the limits. This aspect of the need for superplasticizers becomes obvious in the case of superfine or nano pozzolans like silica fume, nanosilica, and calcined clays. 
Several research reports are already available in the literature presenting concrete composites of very high workability, even with flowing characteristics, with many of these superfine high-end pozzolans. It is also to be noted that the design of these concretes was based on the presently available mix design methodologies of normally vibrated concretes, with only minor adjustments, essentially to the water and superplasticizer requirements wherever necessary. It is probably appropriate to point out at this particular stage that several publications have also taken into account the cementitious strength efficiency of these pozzolans, to design with confidence concretes of the desired strength and performance.

Having looked at all these perspectives one wonders if there is any special concrete composite that needs to be presented under the name of SCC. Extending a little further into what is known, it is obvious that even if we were to term a group of concretes in a special class called SCCs, one cannot be far wrong in saying that these can be designed with the available knowledge and the proposed methodologies for normally vibrated concretes. The later part of this book deals with some of these aspects and also delineates a methodology based on the existing concrete mixed design procedures to ensure a perfectly satisfactory SCC.

\subsection{Definition}

Self-compacting concrete, as the name indicates, is one that has the property of self-consolidating, self-placing, or self-levelling as indicated by several of the alternative names it has in the literature. However, some of the national bodies felt it is prudent to define it as a concrete that confirms to certain qualities, essentially to set it apart from the traditionally vibrated concretes, which in themselves will never come under one single group as can be seen by referring to them as normal concrete, heavyweight concrete, lightweight concrete, high-strength concrete, and even no slump concrete just to name a few. Some of these definitions are presented here to give a clear picture of the perceptions of each of these national bodies.

The Japanese recommendations (1999) define SCCs as concretes with self-compactability, which is defined in the Japanese recommendations as "the capability of concrete related to the placeability of concrete, with which it can be uniformly filled and compacted in every corner of the formwork by its own weight without vibration during placing." This definition essentially talks about its filling ability, though the terms deformability, passability, placeability, and segregation are also defined in the text of the report.

The European guidelines for SCCs (2005) recognize this as "the concrete that is able to flow and consolidate under its own weight, completely fill the 
formwork even in the presence of dense reinforcement, whilst maintaining homogeneity and without the need for any additional compaction." It obviously recognizes filling and passing ability, apart from segregation resistance, as the essential characteristics.

Probably a fairly inclusive definition of SCC is presented by the ACI (2007), which states that "Self-consolidating concrete (SCC) is highly flowable, nonsegregating concrete that can spread into place, fill the formwork, and encapsulate the reinforcement without any mechanical consolidation." It also states that, in general, SCC is concrete made with conventional concrete materials and, in some cases, with a VMA. Apart from all other factors recognized in the earlier definitions, this recognizes the importance of the encapsulation of reinforcement, which is an essential prerequisite for the structural performance of reinforced concrete constructions.

As already stated, the primary aim in each of these definitions, as well as every effort of the research and developmental activities related to SCCs, appears to center around the aspect of self-compactability without giving credence to the fact that this could only be a further extension to the already existing concrete composites at the various consistency levels as defined in the various codes. The fact that it occupies the entire void space in a formwork appears to be reason enough for it to be referred to as a concrete of high performance though this alone is not adequate in practice. Apart from this, if it contains a pozzolanic material like fly ash even just at about $30 \%$ as recommended in most research efforts, one can comfortably consider this to be a concrete of higher performance compared to the concretes without such a pozzolanic replacement using other simple forms of powder extenders that may not help in ensuring such a high performance.

It may not be out of place to have a look at the characteristics that are essential to term a particular concrete as a self-compacting or a SCC - a concrete with the high workability required to flow through densely reinforced structural elements under its own weight and adequately fill voids without segregation or excessive bleeding and without the need for vibration to consolidate it. These characteristics are basically recognized by the Precast/Prestressed Concrete Institute (2003):

Filling ability (flowability)—ability to flow and fill under its own weight all spaces within an intricate formwork, containing obstacles, such as reinforcement.

Passing ability-ability to flow through openings between reinforcement approaching the maximum size of the coarse aggregate without segregation or blocking, and

Stability (segregation resistance)—ability to remain homogeneous during transport, placing, finishing and also through the initial phase of hardening. 


\subsection{Formulations and Classifications of SCCs}

The available procedures for the proportioning of self-consolidating or SCCs could be categorized broadly into three main types. The first is the powder type-essentially increasing the powder content while reducing the water to power ratio to ensure that the aggregates are supported in such a viscous medium of paste and mortar. Alternatively, it was felt that it was possible to generate a similar effect by adding a VMA to provide the same segregation resistance to a concrete of high fluidity. Lastly, a combination of both these methodologies could be used to ensure an optimal utilization of the effects of both.

In every one of these formulations the use of additional powder material content is almost always taken for granted. In the first place the increased powder content can be achieved in two ways either by increasing the cement content, which is highly uneconomical and has its own limits even if one were to consider the increase in strength appropriately, or this can be achieved by using waste powders like stone dust to do the needful. A simple alternative that is presently available is to realize this increase through low-cost, ubiquitously available industrial waste by-products like fly ash and GGBS, which will also perform as low-end secondary cementitious materials. Some researchers also suggest the use of limestone powder readily available in the cement plants as inert filler, though the limestone powder was also observed to be exhibiting some chemical reactivity. Apart from these materials there are several other high-end pozzolanic materials like silica fume, metakaolin, rice husk ash, calcined clays, and so on, which can also be used for this purpose more effectively producing high-strength concretes.

Another important aspect is the fact that while most research reports in general try to classify the concrete as self-compacting once the slump flow is above $500 \mathrm{~mm}$, there are three different slump flow regimes or ranks defined in the various national recommendations. These were also classified into subgroups of SCC based on other characteristics like viscosity or passing ability. SCCs are classified into three different categories or class ranges by JSCE (1999), essentially based on their slump flow characteristics (650-750; 600-700; 500-650 mm as Ranks R1, R2, and R3), basically to suit the needs of the construction conditions, like the minimum gap between reinforcement and the amount of reinforcement to cater to the filling ability needs of the concrete required. Similar classifications based on the parameter of interest are also available in other national specifications like the European and the American. It is in fact said that the choice of the specific characteristic and the subclass or regime of SCC that needs to be adopted essentially stems from the requirements in the field, like the dimensions and intricacy of the structural member, thickness, density of reinforcement, and so on. This in fact is very similar to that for traditionally vibrated concretes, which can be produced with various workabilities or slump, a measure of the workability. Most of the design procedures reported for producing SCCs have concentrated on 
proportioning of the mix constituents to achieve the primary requirement of self-compactability, but have not focused on a procedure to design concrete of a desired strength and workability that characterizes the design of conventional concretes with or without the chemical and mineral admixtures, not to mention the durability aspects.

Having considered all these perspectives, one wonders if there are any special concrete composites that need to be presented under the name of SCCs. Extending a little further into what is known, it is obvious that even if we were to term a group of concretes a special class called self-compacting or SCCs, one cannot be wrong in saying that these can be designed with the available knowledge and the proposed methodologies for normally vibrated concretes. The later part of this book deals with some of these aspects and also delineates a methodology based on existing concrete mixed design procedures to ensure a perfectly satisfactory SCC.

One important aspect that is worth mentioning at this stage is that this study was realized in such a way to ensure that the information collated and the databanks established are comprehensive and are representative of the overall picture and yet they are separated to ensure an appropriate recognition of the intrinsic chemical dynamics of the cementitious systems analyzed. This is to ensure true and representative relationships between the appropriate parameters. The parameters have all been chosen in such a way that they are the most acceptable to date and were seen to have an unequivocal validity in the other systems of cementitious materials that were investigated over the years. Needless to say that the approach is not purely mathematical or empirical as could happen in a case where it is purely governed by the numerical system being analyzed through totally fuzzy or neural logic methods without connecting them to the physical and chemical aspects of the system in question, which could lead to serious misinterpretations. In fact both the spectral width of the data and also the parameters of investigation have always been tempered by an overall understanding of not just the material science and technology of concrete, but also an understanding of its requirement as structural material and its performance in the environment in which these structures are expected to perform. In addition, the possibility of representing not just the concepts but also the outcomes in them in a ready to use format for the practitioner was also attempted wherever possible.

\subsection{Potential and Limitations}

In the present scenario, SCCs can be treated as essentially a newer group of concretes that do not require any compaction energy through vibration or other means. However, as the emphasis is on self-compactability, the more important and defining structural requirements of strength and performance 
have not attracted adequate attention. Naturally, the resulting SCCs, unless appropriately addressed otherwise, may not comply with any specific strength or performance class as required in the structural practice. The discussions in the preceding part of this chapter clearly bring out the fact that SCCs of various strength grades can be appropriately designed if one has better understanding of the specific relations as in the case of traditionally vibrated concretes.

At this stage probably the most important requirement, to fully understand and realize the complete potential of SCCs, is to look at the total picture through a proper appreciation of the concretes reported so far in the literature and arrive at acceptable guidelines and recommendations, not just to arrive at an SCC with the required self-compactability but to be able to design it with an appropriate confidence having the required flowability and also resulting in a concrete of a specific strength and performance grade for a specific structural application. In fact many design efforts essentially started with a very similar objective of obtaining a concrete of a particular strength grade, but the experimental investigations by their own admission have resulted in concretes of different strength grades. Also, the performance characteristics reported, if at all, have not been related to the constituent material characteristics and quantities to ensure an appropriate understanding and adoption. In a few cases, the mechanical characteristics like the tensile strength and modulus are related to the strength, which were observed to be nearly following the accepted relationships used for normally vibrated concretes. This in a way was the justification for an approval of the use of SCCs in structural concrete applications. Even so there are a few who consciously advocated caution in adopting SCCs without an appropriate verification. Some specific aspects like early age characteristics, strength development, shrinkage, bond with reinforcement, and creep, relaxation, and anchorage stress distributions particularly for prestressing applications need a better understanding. There is an urgent need to address some of these aspects at least on a case-to-case basis to ensure safety of the structural systems or alternatively suggest ameliorative measures that could address these concerns based on an appropriate background in such cases from previous experience. It is these important yet fundamental concerns that instigated and initiated the present study to look at the entire spectrum from a structural engineering application standpoint. At the same time appreciating the material science characteristics that are required to ensure an appropriate system of SCCs for practical applications in all the relevant flow regimes is also needed.

\subsection{Future Prospects}

This concept of SCC, originally articulated by Okamura (1994), was seen to be mainly to harness its advantages such as the elimination of vibration and decreasing time and labor costs along with a reduction in noise pollution 
during compaction. It is presumed that it could ensure better durability due to compaction effectiveness and the additional fines that generally are of a pozzolanic nature. The basic difference of SCCs from conventional concretes is in ensuring the three main attributes of filling, passing, and segregation of these concretes through modifications in the proportioning of the constituents, like increasing the fines or by the addition of a VMA that imparts the required segregation resistance.

Most design procedures for SCCs have concentrated on proportioning of the mix constituents to achieve the primary requirement of self-compactability, but have not focused on a procedure to design the concrete of a desired strength and workability that characterizes the design of conventional concretes with or without chemical and mineral admixtures, not to mention aspects of durability. This study is an attempt to discuss the various parameters that influence the making of SCCs and to propose a few simple and effective guidelines to arrive at the same with specific strength and durability characteristics.

\section{References}

ACI 211.1-91, Standard practice for selecting proportions for normal, heavy-weight, and mass concrete, ACI Manual of Concrete Practice, American Concrete Institute, Farmington Hills, MI, 1997, 38pp.

ACI 237R-07, Self-consolidating concrete, ACI Manual of Concrete Practice, American Concrete Institute, Farmington Hills, MI, 2007, 34pp.

Collepardi, M., A very close precursor of self-compacting concrete (SCC), in Supplementary Volume of the Proceedings of Three-Day CANMET/ACI International Symposium on Sustainable Development and Concrete Technology, San Francisco, CA, September 16-19, 2001.

Collepardi, M., Self-consolidating concrete in the presence of fly-ash for massive structures, in Proceedings of Second International Symposium on Concrete Technology for, Sustainable February-Development with Emphasis on Infrastructure, Hyderabad, India, February 27-March 3, 2005, pp. 597-604.

Collepardi, M., Collepardi, S., and Troli, R., Properties of SCC and flowing concrete, in Proceedings of Special Session in Honor of Prof. Giacomo Moriconi, Sustainable Construction Materials and Technologies, Coventry, U.K., June 11-13, 2007, pp. 25-31.

EFNARC, The European Guidelines for Self-Compacting Concrete, Farnham, Surrey, U.K., 2005, p. 68.

Gerwick, B.C., Marine Foundations-Underwater concrete-Mix design and construction practices, 2015.

JSCE, Recommendation for self-compacting concrete, in T. Uomoto and K. Ozawa (Eds.), Concrete Engineering Series 31, 1999, p. 77.

Okamura, H. and Ouchi, M., Self-compacting concrete, Japan Concrete Institute, Journal of Advanced Concrete Technology, 1(1), 2003, 5-15. 
Okamura, H. and Ozawa, K., Self-compactable concrete for bridge construction, in International Workshop on Civil Infrastructural Systems, Taipei, Taiwan, 1994.

Okamura, H. and Ozawa, K., Mix-design for self-compacting concrete, Concrete Library, JSCE, 25, 1995, 107-120.

Precast/Prestressed Concrete Institute, Interim Guidelines for the Use of SelfConsolidating Concrete in Precast/Prestressed Concrete Institute Member Plants, Chicago, IL, TR-6-03, 2003, 165pp.

Semioli, W.J., Self-placing concrete, Concrete International, 23, December 2001, 69-72.

Szecsy, R.S., What's in a name? The Concrete Producer, Washington, January 2002, $51-58$. 


\section{Introduction}

ACl 211.1-91 , Standard practice for selecting proportions for normal, heavy-weight, and mass concrete, $\mathrm{ACl}$ Manual of Concrete Practice, American Concrete Institute, Farmington Hills, MI, 1997, 38pp.

$\mathrm{ACl} 237 \mathrm{R}-07$, Self-consolidating concrete, $\mathrm{ACl}$ Manual of Concrete Practice, American Concrete Institute, Farmington Hills, MI, 2007, 34pp.

Collepardi, M. , A very close precursor of self-compacting concrete (SCC), in Supplementary Volume of the Proceedings of Three-Day CANMET/ACI International Symposium on Sustainable Development and Concrete Technology, San Francisco, CA, September 16-19, 2001.

Collepardi, M. , Self-consolidating concrete in the presence of fly-ash for massive structures, in Proceedings of Second International Symposium on Concrete Technology for, Sustainable February-Development with Emphasis on Infrastructure, Hyderabad, India, February 27-March 3, 2005, pp. 597-604.

Collepardi, M. , Collepardi, S. , and Troli, R. , Properties of SCC and flowing concrete, in Proceedings of Special Session in Honor of Prof. Giacomo Moriconi, Sustainable Construction Materials and Technologies, Coventry, U.K., June 11-13 , 2007, pp. 25-31.

EFNARC , The European Guidelines for Self-Compacting Concrete, Farnham, Surrey, U.K., 2005, p. 68.

Gerwick, B.C. , Marine Foundations-Underwater concrete-Mix design and construction practices, 2015.

JSCE , Recommendation for self-compacting concrete, in T. Uomoto and K. Ozawa (Eds.), Concrete Engineering Series 31, 1999, p. 77.

Okamura, H. and Ouchi, M. , Self-compacting concrete, Japan Concrete Institute, Journal of Advanced Concrete Technology, 1(1), 2003, 5-15.

Okamura, H. and Ozawa, K. , Self-compactable concrete for bridge construction, in International Workshop on Civil Infrastructural Systems, Taipei, Taiwan, 1994.

Okamura, H. and Ozawa, K. , Mix-design for self-compacting concrete, Concrete Library, JSCE, 25, 1995, 107-120.

Precast/Prestressed Concrete Institute , Interim Guidelines for the Use of Self-Consolidating Concrete in Precast/Prestressed Concrete Institute Member Plants, Chicago, IL, TR-6-03, 2003, 165pp.

Semioli, W.J. , Self-placing concrete, Concrete International, 23, December 2001, 69-72.

Szecsy, R.S. , What's in a name? The Concrete Producer, Washington, January 2002, 51-58.

\section{Constituent Materials}

$\mathrm{ACl}$ 363R-84, State of the art report on high strength concrete, ACl Journal, 81(4), 1984, 363-410.

ACI Committee 226 , Use of fly ash in concrete, ACI Material Journal, 84(5), 1987, 381-409. ASTM C 136-95, Standard Test Method for Sieve Analysis of Fine and Coarse Aggregates, Annual Book of ASTM Standards, West Conshohocken, PA, 1995.

ASTM C 150 , Specification for Portland Cement, Annual Book of ASTM Standards, West Conshohocken, PA, 2009.

ASTM C 33 , Standard Specification for Concrete Aggregates, Annual Book of ASTM Standards, 1986.

ASTM C 618 , Specification for Coal Fly Ash and Raw or Calcined Natural Pozzolan for Use as a Mineral Admixture in Portland Cement Concrete, Annual Book of ASTM Standards, West Conshohocken, PA, 1994, pp. 304-306.

ASTM C989, Standard Specification for Ground Granulated Blast-Furnace Slag for Use in Concrete and Mortars, Annual Book of ASTM Standards, West Conshohocken, PA, 1994, pp. 494-498.

BS 882 , Aggregate from natural source for concrete, British Standard Institute, London, U.K., 1973. 
BS EN 12620:2013, Aggregates for concrete, British Standards Institution, London, U.K., 2008. CEB-FIP Model code , Design code 1994, Thomas Telford, London, U.K., 1994.

Dhir, R.K. , Pulverised-fuel ash, in Swamy, R.N. (Ed.), Concrete Technology and Design, Vol. 3, Cement Replacement Materials, Surrey University Press, London, U.K., 1986, pp. 197-255.

DIN 1045 , Beton und Stahlbeton, Beton Verlag GMBH, Koln, Germany, 1988.

EN 197-1, Cement-Part 1: Composition, specifications and conformity criteria for common cements, Brussels, Belgium, 2000, pp. 1-29.

Ganesh Babu, K. , Kiran Kumar, A. , and Pandu Ranga Prasad, R. , Effect of grading on strength and performance of concrete, in Fifth NCB International Conference on Concrete and Concrete Technology for Developing Countries, New Delhi, India, November 1999.

Ganesh Babu, K. and Raja, G.L.V. , Concrete mix specifications for marine environment: An overview, in Third National Conference on Dock and Harbour Engineering, K.R.E.C, Surathkal, India, 1989, pp. 873-877.

Ganesh Babu, K. , Raja, G.L.V. , and Rao, P.S. , Concrete mix design: An appraisal of the current codal provisions, The Indian Concrete Journal, 66(2), 1992, 87-95, 102.

IS 383 , Specification for Coarse and Fine Aggregates from Natural Sources for Concrete, Bureau of Indian Standards, New Delhi, India, 1979.

IS 456 , Code of Practice for Plain and Reinforced Concrete, Bureau of Indian Standards, New Delhi, India, 1979.

Kosmatka, S.H. Kerkhoff, B. , and Panarese, W.C. , Design and Control of Concrete Mixtures, 14th edn., Portland Cement Association, Skokie, IL, 2003.

Mehta, P.K. , Standard specifications for mineral admixtures: An over view, in Proceedings Second International Conference on Fly Ash, Silica Fume, Slag and Natural Pozzolans in Concrete, Madrid, Spain, 1, ACI SP-91, 1986, pp. 639-658.

Mehta, P.K. , Pozzolanic and cementitious by-products in concrete-Another look, in Third International Conference on Fly Ash, Silica Fume, Slag and Natural Pozzolans in Concrete, Trondheim, Norway, ACl, SP-114, 1989, pp. 1-44.

Mehta, P.K. , Concrete: Microstructure, Properties and Materials, First Indian Edition, Indian Concrete Institute, Chennai, India, June 1997.

Mehta, P.K. and Monteiro, P.J. , Concrete: Microstructure, Properties and Materials. McGrawHill, New York, 2006.

Neville, A.M. , Hardened Concrete, Physical and Mechanical Aspects, ACI Monograph No. 6, American Concrete Institute, Detroit, MI, 1971.

Sanchez, F. and Sobolev, K. , Nanotechnology in concrete-A review, Construction and Building Materials, 24, 2010, 2060-2071.

Sellevold, E.J. and Nilsen, T. , Condensed silica fume in concrete: A world review, in Malhotra, V.M. (Ed.), Supplementary Cementing Materials for Concrete, CANMET, Ottawa, Ontario, Canada, SP 86-8E, 1987, pp. 167-246.

Wesche, K. (Ed.), Fly ash in concrete, state of the art report, RILEM TC 67-FAB, 1990.

\section{Insights into Standards and Specifications}

$\mathrm{ACl} 237$, Self-consolidating concrete, $\mathrm{ACl}$ Manual of Concrete Practice, American Concrete Institute, Farmington Hills, MI, 2007, 34pp.

$\mathrm{ACl} 309$, Guide for Consolidation of Concrete, ACl Manual of Concrete Practice, American Concrete Institute, Farmington Hills, MI, 1996, pp. 1-39.

ASTM C124, Method of Test for Flow of Portland-Cement Concrete by Use of the Flow Table (withdrawn 1973), ASTM, West Conshohocken, PA, 1971.

ASTM C1611 , Standard Test Method for Slump Flow of Self-Consolidating Concrete, Annual Book of ASTM Standards, ASTM, West Conshohocken, PA, 2009.

ASTM C1621, Standard Test Method for Passing Ability of Self-Consolidating Concrete by JRing, Annual Book of ASTM Standards, ASTM, West Conshohocken, PA, 2009.

ASTM C172, Standard Practice for Sampling Freshly Mixed Concrete, Annual Book of ASTM Standards, ASTM, West Conshohocken, PA, 2004.

Bartos, P.J.M. , An appraisal of the Orimet Test as a method for on-site assessment of fresh SCC concrete, in International Workshop on Self-Compacting Concrete, Japan, 1998, pp. 
121-135.

Bartos, P.J.M. , Sonebi, M. , and Tamimi, A.K. , Workability and Rheology of Fresh Concrete: Compendium of Tests, RILEM, Cachan, France, 2002.

BS 1881:105:84 , Testing Concrete. Method for Determination of Flow, British Standards Institution, London, U.K., 1984, 10pp.

Daczko, J.A. and Constantiner, D. , Rheodynamic concrete, in 43rd Congresso Brasileiro do Concreto, Brazil, 2001.

DAfStb , DAfStb-Richtlinie Selbstverdichtender Beton (SVB-Richtline)-Teile 1, 2 und 3, Entwurf, DAfStb, Berlin, Germany, September 2012, pp. 1-18.

Domone, P. , Proportioning of self-compacting concrete-The UCL method, UCL, 2009, p. 30. EFNARC , Specification and Guidelines for Self-Compacting Concrete, EFNARC, Surrey, U.K., 2002, p. 32.

EFNARC , The European Guidelines for Self-Compacting Concrete, EFNARC, Surrey, U.K., 2005, p. 68.

EN 12350-1, Testing fresh concrete, Part 1. Sampling fresh concrete, 2000, European Committee for Standardization, Brussels, Belgium, pp. 1-6.

EN 206-1, Concrete-Part 1: Definitions, specifications and quality control, European Committee for Standardization, Brussels, Belgium, 2000, pp. 1-74.

Goodier, C.I. , Development of self-compacting concrete, ICE-Structures and Buildings, 156(4), 2003, 405-414.

Hayakawa, M. , Matsuoka, Y. , and Shindoh, T. , Development and application of superworkable concrete, in RILEM Workshop on Special Concretes Workability and Mixing, 1993, pp. 183-190.

JSCE , Guide to Construction of High Flowing Concrete, Gihoudou Pub., Tokyo, Japan, 1998. JSCE , Recommendation for self-compacting concrete, in T. Uomoto and K. Ozawa (Eds.), Concrete Engineering Series 31, JSCE, Tokyo, Japan, 1999, p. 77.

Lange, D.A. , Self-consolidating concrete. ACBM, Northwestern University, Evanston, IL, 2007, p. 42.

Okamura, H. , Self-compacting high performance concrete, Ferguson Lecture, Concrete International, 19(7), 1997, 50-54.

Okamura, H. and Ouchi, M. , Self-compacting concrete, Journal of Advanced Concrete Technology, 1(1), 2003, 5-15.

Ouchi, M. , Ozawa, K. , and Okamura, H. , Development of simple self-compactability testing method for acceptance at job site, in First International Conference on Concrete Structures, Cairo, Egypt, 1996, pp. 9.11-9.20.

Ozawa, K. , Maekawa, K. , and Okamura, H. , High performance concrete with high filling capacity, Admixtures for Concrete: Improvement of Properties, Proceedings of the International Symposium held by RILEM, May 14-17, 1990, Barcelona, Spain, E. Vazquez (Ed.), Chapman and Hall, London, U.K., 1990, pp. 51-62.

Ozawa, K. , Sakata, N. , and Okamura, H. , Evaluation of self-compactability of fresh concrete using the funnel test, JSCE, 23(490), 1994, 71-80.

Pade, C. , Test methods for SCC, NORDEN Nordic Innovation Centre, Oslo, Norway, 2005, p. 56.

$\mathrm{PCl}$, Interim Guidelines for the Use of Self-Consolidating Concrete in Precast/Prestressed Concrete Institute Member Plants, TR-6-03, Precast/Prestressed Concrete Institute, Chicago, IL, 2003.

Reinhardt, H.W. , DAfStb guideline on self-compacting concrete, Betonwerk und FertigteilTechnik/Concrete Precasting Plant and Technology, 67(12), 2001, 54-58 and 60-62.

Sonebi, M. and Bartos, P.J.M. , Filling ability and plastic settlement of self-compacting concrete, Materials and Structures, 35, 2002, 462-469.

Walraven, J. , Structural applications of self-compacting concrete, in Third RILEM and International Symposium on Self-Compacting Concrete, Reykjavik, Iceland, 2003, pp. 15-22. Wesche, K. , Comparison of different consistency values, RILEM TC 14-CPC, Materials and Structures, 8(45), 1975, 255. 


\section{Methodologies for the Proportioning of SCC Mixtures}

$\mathrm{ACl} 211.1$, Standard Practice for Selecting Proportions for Normal, Heavyweight and Mass Concrete, $\mathrm{ACl}$ Manual of Concrete Practice, American Concrete Institute, Farmington Hills, MI, 1991, 38pp.

$\mathrm{ACl} 211.4$, Guide for Selecting Proportions for High-Strength Concrete with Portland Cement and Fly Ash, $\mathrm{ACl}$ Manual of Concrete Practice, American Concrete Institute, Farmington Hills, MI, 1993, 38pp.

ACl 237R-07, Self-Consolidating Concrete, American Concrete Institute, Farmington Hills, MI, 2007, p. 30pp.

Bouzoubaa, N. and Lachemi, M. , Self-compacting concrete incorporating high volumes of class F fly ash Preliminary results, Cement and Concrete Research, 31, 2001, 413-420.

Bui, V.K. , Akkaya, J. , and Shah, S.P. , Rheological model for self-consolidating concrete, ACI Materials Journal, 99(6), 2002, 549-559.

Collepardi, M. , A very close precursor of self-compacting concrete (SCC), in Symposium on Sustainable Development and Concrete Technology, San Francisco, CA, pp. 431-450, Suppl. Vol., 2001.

Domone, P. , Proportioning of self-compacting concrete-The UCL method, University College London, London, 2009.

Domone, P.L. , Relationships between the fresh properties of SCC and its mortar component, Proceedings of the First North American Conference on the Design and Use of Selfconsolidating Concrete, Chicago, IL, 2002, pp. 37-42.

Domone, P.L. , Self-compacting concrete; An analysis of 11 years of case studies, Cement and Concrete Composites, 28(2), 2006, 197-208.

Domone, P.L. and Jin, J. , Properties of mortar for self-compacting concrete, in RILEM International Symposium on Self-Compacting Concrete, Stockholm, Sweden, 1999, pp. 109-120.

EFNARC , Specification and Guidelines for Self-Compacting Concrete, European Federation of Producers and Applicators of Specialist Products for Structures, Surrey, U.K., 2002.

Euro-EFNARC, Specification and Guidelines for Self-Compacting Concrete, European Federation of Producers and Applicators of Specialist Products for Structures, Surrey, U.K., 2005.

Felekoglu, B. , Turkel, S. , and Baradan, B. , Effect of water/cement ratio on the fresh and hardened properties of self-compacting concrete, Building and Environment, 42(4), 2007, 1795-1802.

Ferrara, L. , Park, Y. , and Shah, S.P. , A method for mix-design of fiber-reinforced selfcompacting concrete, Cement and Concrete Research, 37(6), 2007, 957-971.

Ganesh Babu, K. and Chandra Sekhar, B. , Efficiency of limestone powder in SCC, MRS Proceedings, 1488, 2012, pp. 39-42.

Ganesh Babu, K. , Rao, G.S.N. , and Prakash, P.V.S. , Efficiency of pozzolans in cement composites, in Concrete 2000, Dundee, U.K., Vol. 1, 1993, pp. 497-509.

Ganesh Babu, K. and Siva Nageswara Rao, G. , Efficiency of fly ash in concrete with age, Cement and Concrete Research Journal, 26(3), 1996, 465-474.

Ganesh Babu, K. and Sree Rama Kumar, V. , Efficiency of GGBS in concrete, Cement and Concrete Research Journal, 30(7), 2000, 1031-1036.

Ganesh Babu, K. and Surya Prakash, P.V. , Efficiency of silica fume in concretes, Cement and Concrete Research Journal, 25(6), 1995, 1273-1283.

Grünewald, S. and Walraven, J.C. , Transporting fibres as reinforcement in self-compacting concrete, HERON, 54(2/3), 2009, 101-125.

Hansen, T.C. and Hedegaard, S.E. , Modified rule of constant water content for constant consistency of fresh fly ash concrete mixes, Materials and Structures, 25(6), 1992, 347-354.

$\mathrm{Hu}, \mathrm{J}$. and Wang, K. , Effect of coarse aggregate characteristics on concrete rheology, Construction and Building Materials, 25(3), 2011, 1196-1204.

JSCE , Recommendation for Self-Compacting Concrete, Guidelines for Concrete, No. 31, JSCE, 1999. 
Khaleel, O.R. and Abdul, R.H. , Mix design method for self-compacting metakaolin concrete with different properties of coarse aggregate, Materials and Design, 53, 2014, 691-700.

Khayat, K.H. , Ghezal, A. , and Hadriche, M.S. , Factorial design model for proportioning selfconsolidating concrete, Materials and Structures, 1999, 32(9), 679-686.

Kheder, G.F. and Al Jaidiri, R.S. , New method for proportioning self-consolidating concrete based on compressive strength requirements, ACI Materials, 107(5), 2010, 490-497.

Liu, M. , Wider application of additions in self-compacting concrete, Doctoral thesis, submitted to University College London, 2009, 392pp.

Liu, M. , Self-compacting concrete with different levels of pulverized fuel ash, Construction and Building Materials, 24, 2010, 1245-1252.

Lyse, I. , Tests on consistency and strength of concrete having constant water content, ASTM, 32(2), 1932, 629-636.

Marquardt, I. , Determination of the composition of self-compacting concretes on the basis of the water requirements of the constituent materials: Presentation of a new mix concept, Betonwerk + Fertigteiltechnik BFT, 11, 2002, 22-30.

Marquardt, I. , Diederichs, U. , and Vala, J. , Determination of the optimum water content of SCC mixes, in First North American Conference on the Design and Use of Self-Consolidating Concrete, ACBM, North Western University, Chicago, IL, 2002, pp. 81-88.

Okamura, H. , Self-compacting high-performance concrete, Concrete International, 19, July 1997, pp. 50-54.

Okamura, H. and Ouchi, M. , Self-compacting concrete, Japan Concrete Institute, Journal of Advanced Concrete Technology, 1(1), 2003, 5-15.

Okamura, H. and Ozawa, K. , Mix-design for self-compacting concrete, Concrete Library, JSCE, 25, 1995, 107-120.

Petersson, O. and Billberg, P. , Investigation on blocking of self-compacting concrete with different maximum aggregate size and use of viscosity agent instead of filler, Proceedings of First International RILEM Symposium on Self-Compacting Concrete, Stockholm, Sweden, 1999, pp. 333-344.

Saak, A.W. , Jennings, H.M. , and Shah, S.P. , New methodology for designing self-compacting concrete, ACI Materials Journal, 98(6), 2001, 429-439.

Sebaibi, N. , Benzerzour, M. , Sebaibi, Y. , and Abriak, N. , Composition of self-compacting concrete using the compressible packing model, the Chinese method and the European standard, Construction and Building Materials, 43, 2013, 382-388.

Sedran, T. , de Larrard, F. , Hourst, F. , and Contamines, C. , Mix design of self-compacting concrete, Proceedings of the International RILEM Conference on Production Methods and Workability of Concrete, Paisley, Scotland, 1996, pp. 439-450.

Su, N. , Hsu, K.C. , and Chai, H.W. , A simple mix design method for self-compacting concrete, Cement and Concrete Research, 31, 2001, 1799-1807.

Yu, Z. , Pan, Z. , and Liu, X. , Optimal mixture design of high performance self-compacting concrete, in First International Symposium on Design, Performance and Use of Self-

Consolidating Concrete, Changsha, China, 2005, pp. 181-190.

\section{Concepts and Criteria for High-Performance Self-Compacting Concretes}

Abrams, D.A. , Design of concrete mixtures, Bulletin No.1, Structural Materials Research Laboratory, Lewis Institute, Chicago, IL, 1920, 20pp.

ACI 211.1-91, Standard Practice for Selecting Proportions for Normal Heavyweight, and Mass Concrete, ACI Manual of Concrete Practice, American Concrete Institute, Farmington Hills, MI, 1997, 38pp.

ACl 211.4R-93 , Guide for Selecting Proportions for High-Strength Concrete with Portland Cement and Fly Ash, ACI Manual of Concrete Practice, American Concrete Institute, Farmington Hills, MI, 1998, 13pp.

ACI 237 , Self-Consolidating Concrete, American Concrete Institute, Farmington Hills, MI, 2007, 30pp. 
Appa Rao, Ch.V. , Behaviour of concretes with metakaoline, MS thesis, submitted to Indian Institute of Technology, Madras, India, 2001.

Bijen, J. , and Van Selst, R. , Cement equivalence factors for fly ash, Cement and Concrete Research, 23, 1993, 1029-1039.

BRE (Building Research Establishment), Design of Normal Concrete Mixes, Building Research Establishment, Watford, U.K., 1988, 38p.

Brouwers, H.J.H. and Radix, H.J. , Self-compacting concrete: Theoretical and experimental study, Cement and Concrete Research, 35(11), 2005, 2116-2136.

BS 6588 , Specification for Portland Pulverized-Fuel Ash Cement, British Standards Institution, London, U.K., 1985, p. 18.

BS 6610 , Specification for Pozzolanic Cement with Pulverized-Fuel Ash as Pozzolana, British Standards Institution, London, U.K., 1985, p. 20.

CEB-FIP , Durable Concrete Structures: Design Guide, Thomas Thelford, London, U.K., 1992, p. 128.

CEB-FIP Model Code, Design code, Thomas Thelford, London, U.K., 1994, p. 128.

de Larrard, F. , Concrete Mixture-Proportioning-A Scientific Approach, Modern Concrete Technology Series, No. 9, E \& FN Spon, London, 1999, 421pp.

Dhir, R.K. , Ho, N.Y. , and Munday, J.G.L. , Pulverised fuel ash in structural precast concrete, Concrete, 19(6), June 1985, 32-35.

DIN 1045 , Beton und Stahlbeton, Beton Verlag GMBH, Koln, Germany, 1988.

Domone, P. , Proportioning of self-compacting concrete-the UCL method, 2009.

EFNARC , Specification and Guidelines for Self-Compacting Concrete, EFNARC, Surrey, U.K., 2002, p. 32.

EFNARC, The European Guidelines for Self-Compacting Concrete, EFNARC, Surrey, U.K., 2005, p. 68.

Felekoglu, B. , Turkel, S. , and Baradan, B. , Effect of water/cement ratio on the fresh and hardened properties of self-compacting concrete, Build Environment, 42(4), 2007, 1795-1802.

Ferrara, L. , Park, Y. , and Shah, S.P. , A method for mix-design of fiber-reinforced selfcompacting concrete, Cement and Concrete Research, 37(6), 2007, 957-971.

Funk, J.E. and Dinger, D.R. , Predictive Control of Crowded Particulate Suspension Applied to Ceramic Manufacturing, Kluwer Academic Press, Dordrecht, the Netherlands, 1994.

Ganesh Babu, K. , High performance concrete, in International Symposium on Innovative World of Concrete, ICI-IWC-93, Bangalore, India, Vol. II, September 3, 1993, pp. 169-180.

Ganesh Babu, K. and Chandra Sekhar, B. , Efficiency of limestone powder in SCC, MRS Proceedings, 1488, 2012.

Ganesh Babu, K. and Prakash, P.V.S. , Efficiency of silica fume in concretes, Cement and Concrete Research Journal, 25(6), 1995, 1273-1283.

Ganesh Babu, K. , Raja, G.L.V. , and Srinivasa Rao, P. , Concrete mix design

methodology-An appraisal of the current codal provisions, Indian Concrete Journal, 66, 1992, 87-95.

Ganesh Babu, K. and Rao, G.S.N. , Efficiency of fly ash in concrete with age, Cement and Concrete Research Journal, 26(3), 1996, 465-474.

Ganesh Babu, K. , Rao, G.S.N. , and Prakash, P.V.S. , Efficiency of pozzolans in cement composites, in Concrete 2000, Dundee, U.K., Vol. 1, 1993, pp. 497-509.

Ganesh Babu, K. and Sree Rama Kumar, V. , Efficiency of GGBS in concrete, Cement and Concrete Research Journal, 30(7), 2000, 1031-1036.

Grube, H. , Kerkhoff, B. , and DIN EN 1045-2, The new German concrete standards DIN EN 206-1 and DIN EN 1045-2 as basis for the design of durable constructions, Beton, 51(3), 2001, 19-28.

Hansen, T.C. and Hedegaard, S.E. , Modified rule of constant water content for constant consistency of fresh fly ash concrete mixes, Materials and Structures, 25(6), 1992, 347-354.

Hassaballah, A. and Wanzel, T.H. , Defining the water to cementitious ratio in Fly ash concrete, in Concrete 2000, Vol. 1, 1993, pp. 497-509.

$\mathrm{Hu}, \mathrm{J}$. and Wang, K. , Effect of coarse aggregate characteristics on concrete rheology, Construction and Building Materials, 25(3), 2011, 1196-1204.

IS:10262-1982, Recommended Guidelines for Concrete Mix Design, Bureau of Indian Standards, New Delhi, India, 1983. 
JSCE , Recommendation for Self-Compacting Concrete, Guidelines for Concrete, No. 31, JSCE, Tokyo, Japan, 1999.

Liu, M. , Self-compacting concrete with different levels of pulverized fuel ash, Construction and Building Materials, 24, 2010, 1245-1252.

Marquardt, I. , Determination of the composition of self-compacting concretes on the basis of the water requirements of the constituent materials-Presentation of a new mix concept.

Betonwerk + Fertigteiltechnik BFT, 11, 2002, 22-30.

Munday, J.G.L. , Ong, L.T. , and Dhir, R.K. , Mix proportioning of concrete with PFA : Critical review, Fly Ash, Silica Fume, Slag and Other Mineral Bi-products in concrete, ACI Publication SP-79, Vol. 1, 1983, pp. 267-288.

Narasimhulu, K. , Natural and calcined zeolites in concrete, PhD thesis, submitted to Indian Institute of Technology, Madras, India, 2007.

Neville, A.M. , Properties of Concrete, Longman Scientific \& Technical, Harlow, U.K., 1987. Okamura, H. and Ouchi, M. , Self-compacting concrete, Japan Concrete Institute, Journal of Advanced Concrete Technology, 1(1), 2003, 5-15.

Okamura, H. and Ozawa, K. , Mix-design for self-compacting concrete, Concrete Library, JSCE, 25, 1995, 107-120.

Popovics, S. , What do we know about the contribution of fly ash to the strength of concrete? Second International Conference on Fly Ash, Silica Fume, Slag and Natural Pozzolanas in Concrete, ACI SP-91, 1, 1986, pp. 313-331.

Prakash, P.V.S. , Development and behavioural characteristics of silica fume concretes for aggressive environment, PhD thesis, submitted to IIT Madras, India, May 1996.

Rao, G.S.N. , Effective utilization of fly ash in concretes for aggressive environment, PhD thesis, submitted to IIT, Madras, India, May 1996.

Schiessl, P. and Hardtl, R. , Efficiency of fly ash in concrete-Evaluation of "ibac" test results, Technical Report of Institute fur Bauforschung, RWTH, Aachen, 1991, pp. 1-31.

Sebaibi, N. , Benzerzour, M. , Sebaibi, Y. , and Abriak, N. , Composition of self-compacting concrete using the compressible packing model, the Chinese method and the European standard, Construction and Building Materials, 43, 2013, pp. 382-388.

Sika Services AG Corporate Construction , Sika Concrete Handbook, Sika Services AG Corporate Construction, Zürich, Switzerland, 2005.

Smith, I.A. , The design of fly ash concretes, Proceedings of the Institution of Civil Engineers, London, U.K., 36, 1967, 769-790.

Sree Rama Kumar, V. , Behaviour of GGBS in concrete Composites, MS thesis, submitted to Indian Institute of Technology, Madras, 1999.

Su, N. , Hsu, K.C. , and Chai, H.W. , A simple mix design method for self-compacting concrete, Cement and Concrete Research, 31, 2001, pp. 1799-1807.

Surekha, S. , Performance of rice husk ash concretes, MS thesis, submitted to Indian Institute of Technology, Madras, India, 2005.

Walz, K. , Herstellung von beton nach DIN 1045, Betontechnologische arbeitsunterlagen, Beton-Verlag GmbH, Dusseldorf, Germany, 1971, p. 89.

Yu, Z. , Pan, Z. , and Liu, X. , Optimal mixture design of high performance self-compacting concrete, in First International Symposium on Design, Performance and Use of Self-

Consolidating Concrete, 2005, pp. 181-190.

Zia, P. , Leming, M.L. , and Ahmed, S.H. , High performance concretes: A state-of-the-Art report. SHRP/FR-91-103, North Carolina State University, 1991.

\section{SCCs Based on Powder Extenders and Low-End Pozzolans}

ASTM C989, Standard specification for ground granulated blast-furnace slag for use in concrete and mortars, Annual Book of ASTM Standards, ASTM, West Conshohocken, PA, 1994.

Anagnostopoulos, N. , Sideris, K.K. , and Georgiadis, A. , Mechanical characteristics of selfcompacting concretes with different filler materials, exposed to elevated temperatures, Materials and Structures/Materiaux et Constructions, 42, 2009, 1393-1405. 
Bilodeau, A. and Malhotra, V.M. , High-volume fly ash system: Concrete solution for sustainable development, ACI Materials Journal., 97(1), 2000, 41-48.

Corinaldesi, V. and Moriconi, G. , The role of industrial by-products in self-compacting concrete, Construction and Building Materials, 25, 2011, 3181-3186.

de Larrard, F. , Concrete Mixture Proportioning: A Scientific Approach, E\&FN Spon, London, U.K., 1999.

de Larrard, F. and Sedran, T. , Mixture-proportioning of high-performance concrete, Cement and Concrete Research, 32, 2002, 1699-1704.

Ganesh Babu, K. and Chandra Sekhar, B. , Efficiency of limestone powder in SCC, in MRS Proceedings, p. 1488, 2012. imrc12-1488-7b-039. doi:10.1557/opl.2012.1542.

Ganesh Babu, K. and Rao, G.S.N. , Efficiency of fly ash in concrete, Cement and Concrete Composites, 15, 1993, 223-229.

Ganesh Babu, K. , Rao, G.S.N. and Prakash, P.V.S. , Efficiency of pozzolans in cement composites, in Concrete 2000, Dundee, U.K., Vol. 1, 1993, pp. 497-509.

Ganesh Babu, K. and Sree Rama Kumar, V. , Efficiency of GGBS in concrete, Cement and Concrete Research Journal, 30(7), 2000, 1031-1036.

Ganesh Babu, K. and Sree Rama Kumar, V. , Chloride diffusivity of GGFBS concretes, in Seventh CANMET/ACI International Conference on Fly Ash, Silica Fume, Slag and Natural Pozzolans in Concrete (SP-199), Chennai, Tamilnadu, India, 2001, pp. 611-622.

Ganesh Babu, K. and Surya Prakash, P.V. , Efficiency of silica fume in concretes, Cement and Concrete Research, 25, 1995, 1273-1283.

Ganesh Babu, K. et al. , Design of self compacting concretes with fly ash, in Second North American Conference on the Design and Use of Self-Consolidating Concrete, Center for Advanced Cement-Based Materials, Chicago, IL, 2005a.

Ganesh Babu, K. et al. , Self compacting concrete with fly ash, in Proceedings of the Second International Symposium on Concrete Technology for Sustainable Development, With Emphasis on Infrastructure, American Concrete Institute, Hyderabad, India, 2005b, pp. 605-614.

Ganesh Babu, K. et al. , Fly ash based High Performance Cementitious Composites, in Material Science of Concrete, Special Volume. Indo-US Workshop on High-Performance Cement-Based Concrete Composites, American Ceramic Society, Chennai, Tamilnadu, India, 2005c, pp. 171-182.

Hooton, R.D. and Emery, J.J. , Glass content determination and strength development predictions for vitrified blast furnace slag, ACI SP 79, Detroit, MI, 1983, pp. 943-962.

Khayat, K.H. and Guizani, Z. , Use of viscosity-modifying admixture to enhance stability of fluid concrete, ACI Materials Journal, 94(4), 1997, 332-341.

Khurana, R. and Saccone, R. , Fly ash in self-compacting concrete, fly ash, silica fume, slag and natural pozzolans in concrete, in ACI SP-199, American Concrete Institute, Chennai, Tamilnadu, India, 2001, pp. 259-274.

Kurita, M. and Nomura, T. , Highly-flowable steel fiber-reinforced concrete containing fly ash in Sixth CANMET/ACI/JCI International Conference on Fly Ash, Silica Fume, Slag and Natural Pozzolans in Concrete, Vol. II, Malhotra, V.M. (ed.), Tokushima, Japan, in SP 178, 1998, pp. 159-175.

Kwan, A.K.H. and Mora, C.F. , Effects of various shape parameters on packing of aggregate particles, Magazine of Concrete Research, 53(2), 2001, 91-100.

Miura, N. , Takeda, N. , Chikamatsu, R. , and Sogo, S. , Application of super workable concrete to reinforced concrete structures with difficult construction conditions, in High Performance Concrete in Severe Environments, Zia, P. (ed.), ACI SP 140, Minneapolis, Minnesota, in ACl SP 140, 1993, pp. 163-186.

Okamura, H. and Ozawa, K. , Mix-design for self-compacting concrete, Concrete Library, JSCE, 25, 1995, 107-120.

Okamura, H. , Ozawa, K. , and Ouchi, M. , Self-compacting concrete, Structural Concrete, 1(1), 2000, 3-17.

Ozawa, K. , Maekawa, K. , Kunishima, M. , and Okamura, H. , Performance of concrete based on the durability design of concrete structures, in Second East Asia-Pacific Conference on

Structural Engineering and Construction, Chiang Mai, Thailand, 1989.

Poppe, A. and De Schutter, G. , Heat of hydration in the presence of high filler contents,

Cement and Concrete Research, 2005, 35, 2290-2299. 
Quan, H. , Study on properties of self-compacting concrete with recycled powder, Advanced Materials Research, 250-253, 2011, 866-869.

Ramachandran, V.S. and Zhang, C.M. , Influence of Ca CO3 on the hydration and microstructural characteristics of tricalcium silicate, II Cemento, 3, 1986, 129-152.

Rao, G.S.N. , Effective utilisation of fly ash in concrete for aggressive environments, PhD thesis, submitted to Indian Institute of Technology Madras, Chennai, India, 1996.

Sree Rama Kumar, V. , Behaviour of GGBS in concrete composites, MS thesis, submitted to Indian Institute of Technology Madras, Chennai, India, 1999.

Swamy, R.N. and Bouikni, A. , Some engineering properties of slag concrete as influenced by mix proportioning and curing, ACI Materials Journal, 87, 1990, 210-220.

ACBM , First North American Conference on the Design and Use of Self-Consolidating Concrete ACBM, North Western University, Chicago, IL, 2002.

Askari, A. , Sohrabi, M.R. , and Rahmani, Y. , An investigation into mechanical properties of self compacting concrete incorporating fly ash and silica fume at different ages of curing, Advanced Materials Research, 261-263, 2011, 3-7.

Atan, M.N. and Awang, H. , The mechanical properties of self-compacting concrete incorporating raw rice husk ash, European Journal of Scientific Research, 60(1), 2011, 166-176.

Barbhuiya, S. , Effects of fly ash and dolomite powder on the properties of self compacting concrete, Construction and Building Materials, 25(8), 2011, 3301-3305.

Bouzoubaâ, N. and Lachemi, M. , Self-compacting concrete incorporating high volumes of class F fly ash: Preliminary results, Cement and Concrete Research, 31(3), 2001, 413-420.

Corinaldesi, V. and Moriconi, G. , The role of industrial by-products in self-compacting concrete, Construction and Building Materials, 25(8), 2011, 3181-3186.

Gesog`lu, M. , Güneyisi, E. , and Özbay, E. , Properties of self-compacting concretes made with binary, ternary, and quaternary cementitious blends of fly ash, blast furnace slag, and silica fume, Construction and Building Materials, 23(5), 2009, 1847-1854.

Gesog lu, M. and Özbay, E. , Effects of mineral admixtures on fresh and hardened properties of self-compacting concretes: Binary, ternary and quaternary systems, Materials and

Structures/Materiaux et Constructions, 40(9), 2007, 923-937.

Gheorghe, M. , Saca, N. , Ghecef, C. , Pintoi, R. , and Radu, L. , SELF compacted concrete with fly ash addition, Romanian Journal of Materials, 41(3), 2011, 201-210.

Gorzelańczyk, T. , Moisture influence on the failure of self-compacting concrete under compression, Archives of Civil and Mechanical Engineering, 11(1), 2011, 45-60.

Güneyisi, E. , Gesolu, M. , and Özbay, E. , Strength and drying shrinkage properties of selfcompacting concretes incorporating multi-system blended mineral admixtures, Construction and Building Materials, 24(10), 2010, 1878-1887.

Li, B. , Guan, A. , and Zhou, M. , Preparation and performances of self-compacting concrete used in the joint section between steel and concrete box girders of Edong Yangtze River Highway Bridge, Advanced Materials Research, 168-170, 2011, 334-340.

Ling, T.-C. , Poon, C.-S. , and Kou, S.-C. , Influence of recycled glass content and curing conditions on the properties of self-compacting concrete after exposure to elevated temperatures, Cement and Concrete Composites, 34(2), 2012, 265-272.

Liu, M. , Self-compacting concrete with different levels of pulverized fuel ash, Construction and Building Materials, 24(7), 2010, 1245-1252.

Mňahončáková, E. , Pavlíková, M. , Grzeszczyk, S. , Rovnaníková, P. , and Černý, R. , Hydric thermal and mechanical properties of self-compacting concrete containing different fillers, Construction and Building Materials, 22(7), 2008, 1594-1600.

Poon, C.S. and Ho, D.W.S. , A feasibility study on the utilization of r-FA in SCC, Cement and Concrete Research, 34(12), 2004, 2337-2339.

Quan, H. , Study on properties of self-compacting concrete with recycled powder, Advanced Materials Research, 250-253, 2011, 866-869.

RILEM , Proceedings of the First International RILEM Symposium on SCC, Skarendahl, A. and Petersson, O. (ed.), 1999, 804p.

RILEM , Proceedings of the Third International RILEM Symposium on SCC, Wallevik, O. and Nielsson, I. (ed.), Reykjavik, Iceland, 2003, 1056p.

Siad, H. , Mesbah, H.A. , Bernard, S.K. , Khelafi, H. , and Mouli, M. , Influence of natural pozzolan on the behavior of self-compacting concrete under sulphuric and hydrochloric acid 
attacks, comparative study, Arabian Journal for Science and Engineering, 35(1), 2010, 183-195.

Siddique, R. , Aggarwal, P. , and Aggarwal, Y. , Influence of water/powder ratio on strength properties of self-compacting concrete containing coal fly ash and bottom ash, Construction and Building Materials, 29(6), 2012, 73-81.

Sonebi, M. and Cevik, A. , Genetic programming based formulation for fresh and hardened properties of self-compacting concrete containing pulverised fuel ash, Construction and Building Materials, 23(7), 2009, 2614-2622.

Sukumar, B. , Nagamani, K. , and Srinivasa, R. , Evaluation of strength at early ages of selfcompacting concrete with high volume fly ash, Construction and Building Materials, 22(7), 2008, 1394-1401.

Tao, J. , Yuan, Y. , and Taerwe, L. , Compressive strength of self-compacting concrete during high-temperature exposure, Journal of Materials in Civil Engineering, 22(10), 2010, Art. No. 004010QMT, 1005-1011.

Turk, K. and Karatas, M. , Abrasion resistance and mechanical properties of self-compacting concrete with different dosages of fly ash/silica fume, Indian Journal of Engineering and Materials Sciences, 18(1), 2011, 49-60.

Ulucan, Z.Ç. , Türk, K. , and Karataş, M. , Effect of mineral admixtures on the correlation between ultrasonic velocity and compressive strength for self-compacting concrete, Russian Journal of Nondestructive Testing, 44(5), 2008, 367-374.

Uysal, M. , Yilmaz, K. , and Ipek, M. , Properties and behavior of self-compacting concrete produced with GBFS and FA additives subjected to high temperatures, Construction and Building Materials, 28(1), 2012, 321-326.

Vejmelková, E. , Keppert, M. , Grzeszczyk, S. , Skaliński, B. , and Černý, R. , Properties of selfcompacting concrete mixtures containing metakaolin and blast furnace slag, Construction and Building Materials, 25(3), 2011, 1325-1331.

Xie, Y. , Liu, B. , Yin, J. , and Zhou, S. , Optimum mix parameters of high-strength selfcompacting concrete with ultra pulverized fly ash, Cement and Concrete Research, 32(3), 2002, 477-480.

Zhu, W. , Gibbs, J.C. , and Bartos, P.J.M. , Uniformity of in situ properties of self-compacting concrete in full-scale structural elements, Cement and Concrete Composites, 23(1), 2001, 57-64.

Anagnostopoulos, N. , Sideris, K.K. , and Georgiadis, A. , Mechanical characteristics of selfcompacting concretes with different filler materials, exposed to elevated temperatures, Materials and Structures/Materiaux et Constructions, 42, 2009, 1393-1405.

Assie, S. , Escadeillas, G. , and Waller, V. , Estimates of self-compacting concrete "potential" durability, Construction and Building Materials, 21, 2007, 1909-1917.

Bakhtiyari, S. , Allahverdi, A. , and Rais-Ghasemi, M. , The influence of permanent expanded polystyrene formwork on fire resistance of self-compacting and normal vibrated concretes, Asian Journal of Civil Engineering, 12(3), 2011a, 353-374.

Bakhtiyari, S. , Allahverdi, A. , Rais-Ghasemi, M. , Zarrabi, B.A. , and Parhizkar, T. , Selfcompacting concrete containing different powders at elevated temperatures-Mechanical properties and changes in the phase composition of the paste, Thermochimica Acta, 514, 2011b, 74-81.

Barbhuiya, S. , Effects of fly ash and dolomite powder on the properties of self-compacting concrete, Construction and Building Materials, 25, 2011, 3301-3305.

Benkechkache, G. and Houari, H. , Deferred behaviour of the self compacting concretes based local materials, Asian Journal of Civil Engineering, 12(2), 2011, 219-232.

Bosiljkov, V.B. , SCC mixes with poorly graded aggregate and high volume of limestone filler, Cement and Concrete Research, 33, 2003, 1279-1286.

Boulekbache, B. , Hamrat, M. , Chemrouk, M. , and Amziane, S. , Influence of yield stress and compressive strength on direct shear behavior of steel fibre-reinforced concrete, Construction and Building Materials, 27, 2012, 6-14.

Brouwers, H.J.H. and Radix, H.J. , Self-compacting concrete: Theoretical and experimental study, Cement and Concrete Research, 35, 2005, 2116-2136.

Corinaldesi, V. and Moriconi, G. , The role of industrial by-products in self-compacting concrete, Construction and Building Materials, 25, 2011, 3181-3186.

De Almeida Filho, F.M. , El Debs, M.K. , and El Debs, A.L.H.C. , Bond-slip behavior of selfcompacting concrete and vibrated concrete using pull-out and beam tests, Materials and 
Structures/Materiaux et Constructions, 41, 2008, 1073-1089.

Desnerck, P. , De Schutter, G. , and Taerwe, L. , Bond behaviour of reinforcing bars in selfcompacting concrete: Experimental determination by using beam tests, Materials and Structures/Materiauxet Constructions, 43(SUPPL. 1), 2010, 53-62.

Fares, H. , Remond, S. , Noumowe, A. , and Cousture, A. , High temperature behaviour of selfconsolidating concrete. Microstructure and physicochemical properties, Cement and Concrete Research, 40, 2010, 488-496.

Felekoglu, B. , A comparative study on the performance of sands rich and poor in fines in selfcompacting concrete, Construction and Building Materials, 22, 2008, 646-654.

Filho, F.M.A. , Barragan, B.E. , Casas, J.R. , and El Debs, A.L.H.C. , Hardened properties of self-compacting concrete-A statistical approach, Construction and Building Materials, 24, 2010, 1608-1615.

Georgiadis, A.S. , Sideris, K.K. , and Anagnostopoulos, N.S. , Properties of SCC produced with limestone filler or viscosity modifying admixture, Journal of Materials in Civil Engineering, 22, 2010, 352-360.

Gesog lu, M. and Özbay, E. , Effects of mineral admixtures on fresh and hardened properties of self-compacting concretes: Binary, ternary and quaternary systems, Materials and

Structures/Materiaux et Constructions, 40(9), 2007, 923-937.

Gheorghe, M. , Saca, N. , Ghecef, C. , Pintoi, R. , and Radu, L. , SELF compacted concrete with fly ash addition [Beton Autocompactant Cu CenuÅŸÇŽ ZburÇŽtoare], Revista Romana de Materiale/Romanian Journal of Materials, 41, 2011, 201-210.

Guneyisi, E. , Gesoglu, M. , and Ozbay, E. , Strength and drying shrinkage properties of selfcompacting concretes incorporating multi-system blended mineral admixtures, Construction and Building Materials, 24, 2010, 1878-1887.

Ioani, A. , Domsa, J. , Mircea, C. , and Szilagyi, H. , Durability requirements in self-compacting concrete mix design, Concrete Repair, Rehabilitation and Retrofitting II, Proceedings of the second international conference on Rehabilitation and Retrofitting II, Cape Town, South Africa, 2008, pp. 159-165.

Mňahončáková, E. , Pavlíková, M. , Grzeszczyk, S. , Rovnaníková, P. , and Černý, R. , Hydric thermal and mechanical properties of self-compacting concrete containing different fillers, Construction and Building Materials, 22(7), 2008, 1594-1600.

Nunes, S. , Figueiras, H. , Milheiro, O.P. , Coutinho, J.S. , and Figueiras, J. , A methodology to assess robustness of SCC mixtures, Cement and Concrete Research, 36, 2006, 2115-2122.

Parra, C. , Valcuende, M. , and Gomez, F. , Splitting tensile strength and modulus of elasticity of self-compacting concrete, Construction and Building Materials, 25, 2011, 201-207.

Quan, H. , Study on properties of self-compacting concrete with recycled powder, Advanced Materials Research, 250-253, 2011, 866-869.

Siad, H. , Mesbah, H.A. , Bernard, S.K., Khelafi, H. , and Mouli, M. , Influence of natural pozzolan on the behavior of self-compacting concrete under sulphuric and hydrochloric acid attacks, comparative study, The Arabian Journal for Science and Engineering, 35, 2010, 183-195.

Tao, J. , Yuan, Y. , and Taerwe, L. , Compressive strength of self-compacting concrete during high-temperature exposure, Journal of Materials in Civil Engineering, 2010, 1005-1011.

Uysal, M. , Self-compacting concrete incorporating filler additives: Performance at high temperatures, Construction and Building Materials, 26, 2012, 701-706.

Yurtdas, I. , Burlion, N. , Shao, J.-F. , and Li, A. , Evolution of the mechanical behaviour of a high performance self-compacting concrete under drying, Cement and Concrete Composites, 33, 2011, 380-388.

Anagnostopoulos, N. , Sideris, K.K. , and Georgiadis, A. , Mechanical characteristics of selfcompacting concretes with different filler materials, exposed to elevated temperatures, Materials and Structures/Materiaux et Constructions, 42, 2009, 1393-1405.

Boukendakdji, O. , Kenai, S. , Kadri, E.H. , and Rouis, F. , Effect of slag on the rheology of fresh self-compacted concrete, Construction and Building Materials, 23, 2009, 2593-2598.

Gesoglu, M. , Guneyisi, E. , and Ozbay, E. , Properties of self-compacting concretes made with binary, ternary, and quaternary cementitious blends of fly ash, blast furnace slag, and silica fume, Construction and Building Materials, 23, 2009, 1847-1854.

Guneyisi, E. , Gesoglu, M. , and Ozbay, E. , Strength and drying shrinkage properties of selfcompacting concretes incorporating multi-system blended mineral admixtures, Construction and Building Materials, 24, 2010, 1878-1887. 
Quan, H. , Study on properties of self-compacting concrete with recycled powder, Advanced Materials Research, 250-253, 2011, 866-869.

Siad, H. , Mesbah, H.A. , Bernard, S.K. , Khelafi, H. , and Mouli, M. , Influence of natural pozzolan on the behavior of self-compacting concrete under sulphuric and hydrochloric acid attacks, comparative study, The Arabian Journal for Science and Engineering, 35, 2010, 183-195.

Sonebi, M. and Bartos, P.J.M. , Filling ability and plastic settlement of self-compacting concrete, Materials and Structures/Materiaux et Constructions, 35, 2002, 462-469.

Turkmen, I. , Oz, A. , and Aydin, A.C. , Characteristics of workability, strength, and ultrasonic pulse velocity of SCC containing zeolite and slag, Scientific Research and Essays, 5(15), 2010, 2055-2064.

Uysal, M. , Self-compacting concrete incorporating filler additives: Performance at high temperatures, Construction and Building Materials, 26, 2012, 701-706.

\section{SCCs Based on High Efficiency and Nano Pozzolans}

Ahmadi, M.A. , Alidoust, O. , Sadrinejad, I. , and Nayeri, M. , Development of mechanical properties of self compacting concrete contain rice husk ash, World Academy of Science, Engineering and Technology, 34, 2007, 168-171.

Akcay, B. and Tasdemir, M.A. , Mechanical behaviour and fiber dispersion of hybrid steel fiber reinforced self-compacting concrete, Construction and Building Materials, 28, 2012, 287-293.

Appa Rao, C.V. , Behaviour of concretes with metakaoline, MS thesis, submitted to Indian Institute of Technology Madras, Chennai, India, 2001.

Atan, M.N. and Awang, H. , The mechanical properties of self-compacting concrete incorporating raw rice husk ash, European Journal of Scientific Research, 60(1), 2011, 166-176.

Biricik, H. and Sarier, N. , Comparative study of the characteristics of nano silica-, silica fumeand fly ash-incorporated cement mortars, Materials Research, 17, 2014, 570-582.

Bui, V.K. , Akkaya, J. , and Shah, S.P. , Rheological model for self-consolidating concrete, ACI Materials Journal, 99(6), 2002, 549-559.

Caverzan, A. , Cadoni, E. , and Di Prisco, M. , Dynamic tensile behaviour of self compacting steel fiber reinforced concrete, Applied Mechanics and Materials, 82, 2011, 220-225.

Cohen, M.D. , A look at silica fume and its actions in Portland cements concrete, The Indian Concrete Journal, September 1990, 64, 429-438.

Collepardi, M. , Collepardi, S. , Skarp, U., and Troli, R. , Optimization of silica fume, fly ash and amorphous nano silica in superplasticized high-performance concretes, in Proceeding of Eighth CANMET/ACI International Conference on Fly Ash, Silica Fume, Slag and Natural Pozzolans in Concrete, SP-221, Las Vegas, NV, 2004, pp. 495-506.

Cassagnabère, F. , Mouret, M. , Escadeillas, G. , Broilliard, P. , and Bertrand, A. , Metakaolin, a solution for the precast industry to limit the clinker content in concrete: Mechanical aspects, Construction and Building Materials, 24(7), 2010, 1109-1118.

EFNARC , The European Guidelines for Self-Compacting Concrete, EFNARC, Farnham, Surrey, U.K., 2005, p. 68.

El-Dieb, A.S. , Mechanical, durability and microstructural characteristics of ultra-high-strength self-compacting concrete incorporating steel fibers, Materials and Design, 30, 2009, 4286-4292.

Felekoglu, B. , Tosun, K. , and Baradan, B. , Effects of fiber type and matrix structure on the mechanical performance of self-compacting micro-concrete composites, Cement and Concrete Research, 39, 2009, 1023-1032.

Ferrara, L. , Park, Y. , and Shah, S.P. , A method for mix-design of fiber-reinforced selfcompacting concrete, Cement and Concrete Research, 37(6), 2007, 957-971.

Ganesh Babu, K. and Appa Rao, C.V. , Strength behaviour of concretes containing metakaolin, Paper presented at the Role of Cement Science in Sustainable Development-Proceedings of the International Symposium Dedicated to Professor Fred Glasser, University of Aberdeen,

Scotland, 2003a, pp. 231-239. 
Ganesh Babu, K. and Appa Rao, C.V. , Strength characteristics of metakaolin concretes, in R.K. Dhir (Ed.), International Conference Proceedings, Dundee, U.K., 2003b.

Ganesh Babu, K. and Narasimhulu, K. , Strength efficiency of natural zeolites in concrete composites, Keynote paper in Proceedings of the International Conference on Advances in Concrete and Construction, ICACC, Hydrebad, India, February 2008, pp. 789-798.

Ganesh Babu, K. and Prakash, P.V.S. , Effective utilisation of lower grade silica fume in the production of high strengtth concretes, in Fourth NCB International Seminar on Cement and Building Materials, New Delhi, India, December 1994, Vol. 4, pp. XI, $26-32$.

Ganesh Babu, K. and Prakash, P.V.S. , Efficiency of silica fume in concrete, Cement and Concrete Research, 25(6), 1995, 1273-1283.

Ganesh Babu, K. and Prakash, P.V.S. , Sorptivity characteristics of silica fume concretes, in Proceedings of International Seminar on "Civil Engineering Practices in Twenty First Century", Roorkee, India, February 1996, Vol. II, pp. 788-797.

Ganesh Babu, K. and Prakash, P.V.S. , Deterioration of silica fume concretes due to sulphate attack, in International Symposium on Innovative World of Concrete, Calcutta, India, November 1998, Vol. 2, pp. 6.61-6.69.

Ganesh Babu, K. , Rao, G.S.N. , and Prakash, P.V.S. , Efficiency of pozzolans in cement composites, in R.K. Dhir and R. Jones (Eds.), Concrete 2000, Vol. 1, E\&FN Spon, Dundee, U.K., 1993, pp. 497-509.

Grünewald, S. and Walraven, J.C. , Transporting fibers as reinforcement in self-compacting concrete, HERON, 54(2/3), 2009, 101-125.

Guneyisi, E. , Gesoglu, M. , and Ozbay, E. , Strength and drying shrinkage properties of selfcompacting concretes incorporating multi-system blended mineral admixtures, Construction and Building Materials, 24, 2010a, 1878-1887.

Ioani, A. , Domsa, J. , Mircea, C. , and Szilagyi, H. , Durability requirements in self-compacting concrete mix design, Concrete Repair, Rehabilitation and Retrofitting II-Proceedings of the Second International Conference on Concrete Repair, Rehabilitation and Retrofitting, Cape Town, South Africa, 2008, pp. 159-165.

Jalal, M. , Mansouri, E. , Sharifipour, M. , and Pouladkhan, A.R. , Mechanical, rheological, durability and microstructural properties of high performance self-compacting concrete containing SiO2 micro and nanoparticles, Materials and Design, 34, 2012, 389-400.

Li, B. , Guan, A. , and Zhou, M. , Preparation and performances of self-compacting concrete used in the joint section between steel and concrete box girders of Edong Yangtze River Highway Bridge, Advanced Materials Research, 168-170, 2011, 334-340.

Liu, M. , Self-compacting concrete with different levels of pulverized fuel ash, Construction and Building Materials, 24, 2010, 1245-1252.

Maghsoudi, A.A. , Soheil, M.J. , and Darbhenz, A. , Effect of the nano particles in the new generation of concretes, SCC, International Journal of Nanoscience and Nanotechnology, 6(3), September 2010, 137-143.

Mazaheripour, H. , Ghanbarpour, S. , Mirmoradi, S.H. , and Hosseinpour, I. , The effect of polypropylene fibers on the properties of fresh and hardened lightweight self-compacting concrete, Construction and Building Materials, 25, 2011, 351-358.

Mehta, P.K. , Rice husk ash-A unique supplementary cementitious material, in V.M. Malhotra (Ed.), Proceedings of the International Symbosium on Advances in Concrete Technology,

CANMET, Concord, NH, 1994, pp. 419-443.

Montgomery, J. , Abu-Lebdeh, T.M. , Hamoush, S.A. , and Picornell, M. , Effect of nano silica on the compressive strength of harden cement paste at different stages of hydration, American Journal of Engineering and Applied Sciences, 9(1), 2016, 166-177.

Narasimhulu, K. , Natural and calcined zeolites in concrete, PhD thesis, submitted to Indian Institute of Technology Madras, Chennai, India, 2007.

Neville, A.M. , Properties of Concrete, 4th ed., Longman, London, U.K., 1995.

Prakash, P.V.S. , Development and behavioural characteristics of silica fume concretes for aggressive environment, PhD thesis, submitted to Indian Institute of Technology Madras, Chennai, India, 1996.

Quercia, G. , Spiesz, P. , Hüsken, G. , and Brouwers, H.J.H. , SCC modification by use of amorphous nano-silica, Cement and Concrete Composites, 45, 2014, 69-81.

Rahmani, Y. , Sohrabi, M.R. , and Askari, A. , Mechanical properties of rubberized selfcompacting concrete containing silica fume, Advanced Materials Research, 262-263, 2011a, 441-445. 
Saak, A.W. , Jennings, H.M. , and Shah, S.P. , New methodology for designing self-compacting concrete, ACI Materials Journal, 98(6), 2001, 429-439.

Sellevold, E.J. and Nilsen, T. , Condensed silica fume in concrete: A world review, in V.M. Malhotra (Ed.), Supplementary Cementing Materials for Concrete, CANMET, Ottawa, ON, Canada, ACl-SP-86, 1987, pp. 167-246.

Su, N. , Hsu, K.-C. , and Chai, H.-W. , A simple mix design method for self-compacting concrete, Cement and Concrete Research, 31, 2001, 1799-1807.

Sua-lam, G. and Makul, N. , The use of residual rice husk ash from thermal power plant as cement replacement material in producing self-compacting concrete, Advanced Materials Research, 415-417, 2012, 1490-1495.

Surekha, S. , Performance of rice husk ash concretes, MS thesis, submitted to Indian Institute of Technology Madras, Chennai, India, 2005.

Turk, K. and Karatas, M. , Abrasion resistance and mechanical properties of self-compacting concrete with different dosages of fly ash/silica fume, Indian Journal of Engineering and Materials Sciences, 18, 2011a, 49-60.

Turk, K. , Turgut, P. , Karatas, M. , and Benli, A. , Mechanical properties of self-compacting concrete with silica fume/fly ash, in Ninth International Congress on Advances in Civil Engineering, Trabzon, Turkey, September 27-30, 2010a, pp. 1-7.

Türkmen, I. , Oz, A. , and Aydin, A.C. , Characteristics of workability, strength, and ultrasonic pulse velocity of SCC containing zeolite and slag, Scientific Research and Essays, 5(15), 2010, 2055-2064.

Ulucan, Z.C. , Turk, K. , and Karatas, M. , Effect of mineral admixtures on the correlation between ultrasonic velocity and compressive strength for self-compacting concrete, Russian Journal of Nondestructive Testing, 44(5), 2008a, 367-374.

Vejmelkova, E. , Keppert, M. , Grzeszczyk, S. , Skalinski, B. , and Cerny, R. , Properties of selfcompacting concrete mixtures containing metakaolin and blast furnace slag, Construction and Building Materials, 25, 2011, 1325-1331.

Zia, P. , Leming, M.L. , and Ahmed, S.H. , High performance concretes: A state of the Art report, SHRP/FR 91-103, North Carolia State University, Raleigh, NC, 1991.

Guneyisi, E. , Gesoglu, M. , and Ozbay, E. , Strength and drying shrinkage properties of selfcompacting concretes incorporating multi-system blended mineral admixtures, Construction and Building Materials, 24, 2010b, 1878-1887.

Ioani, A. , Domsa, J. , Mircea, C. , and Szilagyi, H. , Durability requirements in self-compacting concrete mix design, Concrete Repair, Rehabilitation and Retrofitting II-Proceedings of the Second International Conference on Concrete Repair, Rehabilitation and Retrofitting II, Cape Town, South Africa, 2008, pp. 159-165.

Jalal, M. , Mansouri, E. , Sharifipour, M. , and Pouladkhan, A.R. , Mechanical, rheological, durability and microstructural properties of high performance self-compacting concrete containing SiO2 micro and nanoparticles, Materials and Design, 34, 2012, 389-400.

Rahmani, Y. , Sohrabi, M.R. , and Askari, A. , Mechanical properties of rubberized self compacting concrete containing silica fume, Advanced Materials Research, 262-263, 2011b, 441-445.

Sebaibi, N. , Benzerzour, M. , Sebaibi, Y. , and Abriak, N. , Composition of self-compacting concrete (SCC) using the compressible packing model, the Chinese method and the European standard, Construction Building Materials, 43, 2013, 382-388.

Turk, K. and Karatas, M. , Abrasion resistance and mechanical properties of self-compacting concrete with different dosages of fly ash/silica fume, Indian Journal of Engineering and Materials Sciences, 18, 2011b, 49-60.

Turk, K. , Turgut, P. , Karatas, M. , and Benli, A. , Mechanical properties of self-compacting concrete with silica fume/fly ash, in Ninth International Congress on Advances in Civil Engineering, Trabzon, Turkey, September 27-30, 2010b, pp. 1-7.

Ulucan, Z.C. , Turk, K. , and Karatas, M. , Effect of mineral admixtures on the correlation between ultrasonic velocity and compressive strength for self-compacting concrete, Russian Journal of Nondestructive Testing, 44(5), 2008b, 367-374. 


\section{Fresh Concrete Characteristics of SCCs}

$\mathrm{ACl}$ Committee 309 , Recommended Practice for Consolidation of Concrete, $\mathrm{ACl} 309-72, \mathrm{ACl}$ Manual of Concrete Practice, Part 2, American Concrete Institute, Detroit, MI, 1984.

ASTM C 684-99, Standard Method of Making, Accelerated Curing, and Testing for Concrete Compression Test Specimens, American Society for Testing and Materials, West Conshohocken, PA, 2003.

Bartos, P. , Fresh Concrete: Properties and Tests, Elsevier, 1992.

Bartos, P.J.M. , An appraisal of the Orimet Test as a method for on-site assessment of fresh SCC concrete, Proceedings of International Workshop on Self-Compacting Concrete, Kochi University of Technology, Japan, 1998, pp. 121-135.

Billberg, P. , Influence of filler characteristics on SCC rheology and early hydration, in Proceedings of Second International Symposium on Self-Compacting Concrete, Ozawa, K. and Ouchi, M. (Eds.), COMS Engineering Corporation, Tokyo, Japan, 2001, pp. 285-294.

Bouzoubaa, N. and Lachemi, M. , Self-compacting concrete incorporating high volumes of class F fly ash: Preliminary results, Cement and Concrete Research, 31, 2001, 413-420.

Brouwers, H.J.H. and Radix, H.J., Self-compacting concrete: Theoretical and experimental study, Cement and Concrete Research, 35, 2005, 2116-2136.

BS 1881: Part 112 , Methods of Accelerated Curing of Test Cubes, British Standards Institution, London, U.K., 1983.

Cussigh, F. , SCC in practice: Opportunities and bottlenecks. In Proceedings of the Fifth International RILEM Symposium on SCC, De Schutter, G. and Boel, V. (Eds.), Ghent, Belgium, 2007, pp. 21-28.

DAfStb , DAfStb-Richtlinie Selbstverdichtender Beton (SVB-Richtline)-Teile 1, 2 und 3, Entwurf, DAfStb, Berlin, September 2012, pp. 1-18.

de Larrard, F. , Ferraris, C.F. , and Sedran, T. , Fresh concrete: A Herschel-Bulkley material, Materials and Structures, 31, 1998, 494-498.

DIN 1045 , Beton und Stahlbeton, Beton Verlag GMBH, Koln, Germany, 1988.

EFNARC , The European guidelines for self-compacting concrete, EFNARC, Farnham, Surrey, U.K., 2005, p. 68.

El-Dieb, A.S. , Mechanical, durability and microstructural characteristics of ultra-high-strength self-compacting concrete incorporating steel fibers, Materials and Design, 30, 2009, 4286-4292.

EN 12350-1, Testing fresh concrete, Part 1. Sampling fresh concrete, European committee for standardization, Brussels, Belgium, 2000, pp. 1-6.

Felekoglu, B. , Turkel, S. , and Baradan, B. , Effect of water/cement ratio on the fresh and hardened properties of self-compacting concrete, Building and Environment, 42, 2007, 1795-1802.

Ferraris, C. and Brower, L. , Comparison of concrete rheometers: International tests at LCPC (Nantes, France) in October 2000, National Institute of Standards and Technology (NISTIR) 6819, Gaithersburg, MD, September 2001.

Ganesh Babu, K. et al. , Design of self-compacting concretes with fly ash, in Second North American Conference on the Design and Use of Self-Consolidating Concrete, Center for Advanced Cement-Based Materials, Chicago, IL, 2005a.

Ganesh Babu, K. et al. , Fly ash based high performance cementitious composites, material science of concrete, in Indo-US Workshop on High-Performance Cement-Based Concrete Composites, American Ceramic Society, Chennai, India, 2005b, pp. 171-182.

Ganesh Babu, K. et al. , Self-compacting concrete with fly ash, in ACI Sponsored Second International Symposium on Concrete Technology for Sustainable Development, with Emphasis on Infrastructure, Hyderabad, India, 2005c, pp. 605-614.

Georgiadis, A.S. , Sideris, K.K. , and Anagnostopoulos, N.S. , Properties of SCC produced with limestone filler or viscosity modifying admixture, Journal of Materials in Civil Engineering, 22(4), 2009, 352-360.

Gesoglu, M. , Guneyisi, E. , and Ozbay, E. , Properties of self-compacting concretes made with binary, ternary, and quaternary cementitious blends of fly ash, blast furnace slag, and silica 
fume, Construction and Building Materials, 23, 2009, 1847-1854.

Gesoglu, M. and Ozbay, E. , Effects of mineral admixtures on fresh and hardened properties of self-compacting concretes: Binary, ternary and quaternary systems, Materials and

Structures/Materiaux et Constructions, 40, 2007, 923-937.

Guneyisi, E. and Gesoglu, M. , Properties of self-compacting mortars with binary and ternary cementitious blends of fly ash and metakaolin, Materials and Structures, 41, 2008, 1519-1531.

Guneyisi, E. , Gesoglu, M. , and Ozbay, E. , Strength and drying shrinkage properties of selfcompacting concretes incorporating multi-system blended mineral admixtures, Construction and Building Materials, 24, 2010, 1878-1887.

Hwang, S. , Khayat, K.H. , and Bonneau, O. , Performance-based specifications of selfconsolidating concrete used in structural applications, ACI Materials Journal, 103(2), 2006, 121-129.

IS: 9013-1978, Method of Making, Curing and Determining Compressive Strength of Accelerated Cured Concrete Test Specimens, Bureau of Indian Standards, 1998.

Kantro, D.L. , Influence of water reducing admixtures on properties of cement pastes-A miniature slump test, Cement Concrete Aggregates, 2, 1980, 95-102.

Khayat, K.H. , Manai, K. , and Trudel, A. , In situ mechanical properties of wall elements cast using self-consolidating concrete, ACI Materials Journal, 94, 1997, 491-500.

Kheder, G.F. and Al Jadiri, R.A. , New method for proportioning self-consolidating concrete based on compressive strength requirements, ACI Materials Journal, 107(5), 2010, 490-497.

Koehler, E.P. and Fowler, D.W. , Summary of concrete workability test methods, ICAR Report 105.1, International Center for Aggregates Research, Austin, TX, August 2003, 76pp.

Kovler, K. and Roussel, N. , Properties of fresh and hardened concrete, Cement and Concrete Research, 41, 2011, 775-792.

$\mathrm{Li}, \mathrm{J}$. , Configuration of low-strength self-compacting concrete adapted to local raw materials, Advanced Materials Research, 335-336, 2011, 1159-1162.

Liu, M. , Self-compacting concrete with different levels of pulverized fuel ash, Construction and Building Materials, 24, 2010, 1245-1252.

Marquardt, I. , Diederichs, U. , and Vala, J. , Determination of the composition of self compacting concretes on the basis of the water requirements of the constituents materials, Betonwerk + Fertigteil-Technik, 68(11), 2002, 22-29 (in German and English).

Mazaheripour, H. , Ghanbarpour, S. , Mirmoradi, S.H. , and Hosseinpour, I. , The effect of polypropylene fibers on the properties of fresh and hardened lightweight self-compacting concrete, Construction and Building Materials, 25, 2011, 351-358.

Melo, K.A. and Carneiro, A.M.P. , Effect of metakaolin's finesses and content in selfconsolidating concrete, Construction and Building Materials, 24, 2010, 1529-1535.

Okamura, H. and Ozawa, K. , Mix-design for self-compacting concrete, Concrete Library, JSCE, 25, 1995, 107-120.

Olsen, M.P.J. , Energy requirements for consolidation of concrete during internal vibration, Consolidation of concrete, ACI SP-86, American Concrete Institute, Detroit, 1987, pp. 179-196. Pade, C. , Test methods for SCC, Nordic Innovation Centre, project number: 02128, December 2005, 56p.

Prakash, P.V.S. , Development and behavioural characteristics of silica fume concretes for aggressive environment, PhD thesis, submitted to IIT Madras, Chennai, India, May 1996.

Quan, H. , Study on properties of self-compacting concrete with recycled powder, Advanced Materials Research, 250-253, 2011, 866-869.

Rao, G.S.N. , Effective utilization of fly ash in concretes for aggressive environment, PhD thesis, submitted to IIT Madras, Chennai, India, May 1996.

Reinhardt, H.W. , DAfStb guideline on self compacting concrete, Betonwerk und FertigteilTechnik/Concrete Precasting Plant and Technology, 67(12), 2001, 54-58 + 60-62.

Roussel, N. and Cussigh, F. , Distinct-layer casting of SCC: The mechanical consequences of thixotropy, Cement and Concrete Research, 38, 2008, 624-632.

Saak, A.W. , Jennings, H.M. , and Shah, S.P. , New methodology for designing self-compacting concrete, ACI Materials Journal, 98(6), 2001, 429-439.

Skarendahl, A. and Petersson, O. , Self compacting concrete, state of the art report of RILEM

TC 174-SCC, Report 23, RILEM Publications, Cachan, France, 2000.

Sonebi, M. , Medium strength self-compacting concrete containing fly ash: Modelling using

factorial experimental plans, Cement and Concrete Research, 34, 2004, 1199-1208. 
Sonebi, M. and Bartos, P.J.M. , Filling ability and plastic settlement of self-compacting concrete, Materials and Structures, 35, 2002, 462-469.

Sonebi, M. and Cevik, A. , Prediction of fresh and hardened properties of self-consolidating concrete using neurofuzzy approach, Journal of Materials in Civil Engineering, 21(11), 2009a, 672-679.

Sonebi, M. and Cevik, A. , Genetic programming based formulation for fresh and hardened properties of self-compacting concrete containing pulverised fuel ash, Construction and Building Materials, 23, 2009b, 2614-2622.

Su, N. , Hsu, K.-C. , and Chai, H.-W. , A simple mix design method for self-compacting concrete, Cement and Concrete Research, 31, 2001, 1799-1807.

Sukumar, B. , Nagamani, K. , and Srinivasa Raghavan, R. , Evaluation of strength at the early ages of self-compacting concrete with high volume fly ash, Construction and Building Materials, 22(7), 2008, 1394-1401.

Tatersall, G.H. , Workability and Quality-Control of Concrete, E \& FN SPON, London, U.K., 1991.

Turk, K. , Caliskan, S. , and Yazicioglu, S. , Capillary water absorption of self-compacting concrete under different curing conditions, Indian Journal of Engineering and Materials Sciences, 14, 2007, 365-372.

Turk, K. , Turgut, P. , Karatas, M. , and Benli, A. , Mechanical properties of self-compacting concrete with silica fume/fly ash, in Ninth International Congress on Advances in Civil Engineering, September 27-30, 2010, pp. 1-7.

Turkmen, I. and Kantarci, A. , Effects of expanded perlite aggregate and different curing conditions on the physical and mechanical properties of self-compacting concrete, Building and Environment, 42, 2007, 2378-2383.

Walraven, J. , Structural applications of self-compacting concrete, in Third RILEM and International symposium on self-compacting concrete, Reykjavik, Iceland, 2003, pp. 15-22.

\section{Mechanical Characteristics of SCCs}

Ahmadi, M.A. , Alidoust, O. , Sadrinejad, I. , and Nayeri, M. , Development of mechanical properties of self compacting concrete contain rice husk ash, World Academy of Science, Engineering and Technology, 34, 2007, 168-171.

Ahmed, F.M. , Nuruddin, F.M. , and Shafiq, N. , Compressive strength and workability characteristics of low-calcium fly ash-based self-compacting geopolymer concrete, Proceedings of World Academy of Science, Engineering and Technology, 5(2), 2011, 64-70.

Akcay, B. and Tasdemir, M.A. , Mechanical behaviour and fibre dispersion of hybrid steel fibre reinforced self-compacting concrete, Construction and Building Materials, 28, 2012, 287-293.

Al Salami, S.T. , Mechanical properties of conventional and self-compacting concrete as related to the mechanical properties of their binding mortar, MSc thesis, University of Mustansiriya, Baghdad, Iraq, April 2008, 119pp.

Altin, M. , Saritas, I. , Cogurcu, M.T. , Tasdemir, S. , Kamanli, M. , and Kaltakci, M.Y. , Determination of the resistance characteristics of self-compacting concrete samples by Artificial Neural Network, in Proceedings of the Ninth International Conference on Computer Systems and Technologies and Workshop for PhD Students in Computing, CompSysTech'08, Technical University-Gabrovo, Bulgaria, 2008.

Ambroise, J. and Pera, J. , Design of self-leveling concrete, in Shah, S.P. , Daczko, J.A. , and Lingscheit, J.N. (Eds.), First North American Conference on the Design and Use of SelfConsolidating Concrete, ACBM, North Western University, Chicago, 2002, pp. 89-94. Appa Rao, C.V. , Behaviour of concretes with metakaoline, MS thesis, submitted to Indian Institute of Technology Madras, Chennai, India, 2001.

Askari, A. , Sohrabi, M.R. , and Rahmani, Y. , An investigation into mechanical properties of self-compacting concrete incorporating fly ash and silica fume at different ages of curing, Advanced Materials Research, 261-263, 2011, 3-7.

Atan, M.N. and Awang, H. , The compressive and flexural strengths of self-compacting concrete using raw rice husk ash, Journal of Engineering Science and Technology, 6(6), 2011, 720-732. 
Bonen, D. and Shah, S.P. , Effects of formulations on the properties of self-consolidating concrete, in Concrete Science and Engineering: A Tribute to Arnon Bentur, International RILEM Symposium, Kovler, K. , Marchand, J. , Mindess, S. , and Weiss, J. (Eds.), in Third RILEM Symposium on Self-Compacting Concrete, Reykjavik, Iceland, 2004, pp. 43-56.

Bosiljkov, V.B. , SCC mixes with poorly graded aggregate and high volume of limestone filler, Cement and Concrete Research, 2003, 33, 1279-1286.

Boukendakdji, O. , Kadri, E.-H. , and Kenai, S. , Effects of granulated blast furnace slag and superplasticizer type on the fresh properties and compressive strength of self-compacting concrete, Cement and Concrete Composites, 34(4), 2012, 583-590.

Cassagnabere, F. , Mouret, M. , Escadeillas, G. , Broilliard, P. , and Bertrand, A. , Metakaolin, a solution for the precast industry to limit the clinker content in concrete: Mechanical aspects, Construction and Building Materials, 24, 2010, 1109-1118.

Caverzan, A. , Cadoni, E. , and Di Prisco, M. , Dynamic tensile behaviour of self-compacting steel fibre reinforced concrete, Applied Mechanics and Materials, 82, 2011, 220-225.

CEB , Diagnosis and Assessment of Concrete Structures-State-of-Art Report, Bulletin No 192, 1989, p. 120.

Dehn, F. , Holschemacher, K. , and Weibe, D. , Self-compacting concrete (SCC) time development of the material properties and the bond behavior, LACER, 5, 2000, 115-124.

Dehwah, H.A.F. , Mechanical properties of self-compacting concrete incorporating quarry dust powder, silica fume or fly ash, Construction and Building Materials, 26, 2012, 547-551.

Desnerck, P. , De Schutter, G. , and Taerwe, L. , Bond behaviour of reinforcing bars in selfcompacting concrete: Experimental determination by using beam tests, Materials and Structures, 43, 2010, 53-62.

Domone, P.L. , A review of the hardened mechanical properties of self-compacting concrete, Cement and Concrete Composites, 29(1), 2007, 1-12.

Druta, C. , Tensile strength and bonding characteristics of self-compacting concrete, MSc thesis, Louisiana State University, Baton Rouge, LA, August 2003, 108pp.

El-Dieb, A.S. , Mechanical, durability and microstructural characteristics of ultra-high-strength self-compacting concrete incorporating steel fibers, Materials and Design, 30, 2009, 4286-4292.

Esping, O. , Effect of limestone filler BET(H2O)-area on the fresh and hardened properties of self-compacting concrete, Cement and Concrete Research, 38, 2008, 938-944.

Felekoglu, B. , Turkel, S. , and Baradan, B. , Effect of water/cement ratio on the fresh and hardened properties of self-compacting concrete, Building and Environment, 42, 2007, 1795-1802.

Filho, F.M.A. , Barragan, B.E. , Casas, J.R. , and El Debs, A.L.H.C. , Hardened properties of self-compacting concrete-A statistical approach, Construction and Building Materials, 24, 2010, 1608-1615.

Ganesh Babu, K. and Siva NageswaraRao, G. , Efficiency of fly ash in concrete with age, Cement and Concrete Research Journal, 26(3), 1996, 465-474.

Gencel, O. , Ozel, C. , Brostow, W. , and Martinez-Barrera, G. , Mechanical properties of selfcompacting concrete reinforced with polypropylene fibres, Materials Research Innovations, 15(3), 2011, 216-225.

Gesog lu, M. , Güneyisi, E. , and Özbay, E. , Properties of self-compacting concretes made with binary, ternary, and quaternary cementitious blends of fly ash, blast furnace slag, and silica fume, Construction and Building Materials, 23, 2009, 1847-1854.

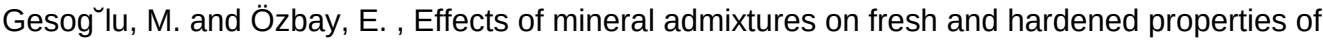
self-compacting concretes: Binary, ternary and quaternary systems, Materials and

Structures/Materiaux et Constructions, 40, 2007, 923-937.

Gheorghe, M. , Saca, N. , Ghecef, C. , Pintoi, R. , and Radu, L. , SELF compacted concrete with fly ash addition [Beton Autocompactant Cu Cenusa Zburatoare], Revista Romana de Materiale/Romanian Journal of Materials, 41(3), 2011, 201-210.

Glasser, F.P. , Chemistry of cement-Solidified waste forms, in Spence, R.D. (Ed.), Chemistry and Microstructure of Solidified Waste Forms, Lewis Publishers, Boca Raton, FL, 1993, pp. $1-40$.

Güneyisi, E. and Gesog $ॅ$ lu, M. , Properties of self-compacting mortars with binary and ternary cementitious blends of fly ash and metakaolin, Materials and Structures, 41, 2008, 1519-1531. 
Güneyisi, E. , Gesoğlu, M. , and Özbay, E. , Strength and drying shrinkage properties of selfcompacting concretes incorporating multi-system blended mineral admixtures, Construction and Building Materials, 24(10), 2010, 1878-1887.

Holschemacher, K. and Klug, Y. , A database for the evaluation of hardened properties of SCC, LACER, 7, 2002, 124-134.

Hunger, M. , Entrop, A.G. , Mandilaras, I. , Brouwers, H.J.H. , and Founti, M. , The behavior of self-compacting concrete containing micro-encapsulated Phase Change Materials, Cement and Concrete Composites, 31, 2009, 731-743.

Jahren, P. , Use of silica fume in concrete, ACI SP-79, First CANMET/ACI International Conference, SP-79, Malhotra, V.M. (Ed.), Vol. II, 1983, pp. 625-642.

Jalal, M. , Mansouri, E. , Sharifipour, M. , and Pouladkhan, A.R. , Mechanical, rheological, durability and microstructural properties of high performance self-compacting concrete containing SiO2 micro and nanoparticles, Materials and Design, 34, 2012, 389-400.

Khatib, J.M. , Performance of self-compacting concrete containing fly ash, Construction and building materials, 22(9), 2008, 1963-1971.

Khayat, K.H. , Petrov, N. , Attiogbe, E.K. , and See, H.T. , Uniformity of bonds strength of prestressing strands in conventional flowable and self-consolidating concrete mixtures, in Third RILEM Symposium on Self-Compacting Concrete, Reykjavik, Iceland, 2003, pp. 703-712. Kheder, G.F. and Al Jadiri, R.A. , New method for proportioning self-consolidating concrete based on compressive strength requirements, ACI Materials Journal, 2010, 490-497.

Kou, S.C. and Poon, C.S. , Properties of self-compacting concrete prepared with recycled glass aggregate, Cement and Concrete Composites, 31, 2009, 107-113.

Leemann, A. and Hoffmann, C. , Properties of self-compacting and conventional concretedifferences and similarities, Magazine of Concrete Research, 57(6), 2005, 315-319.

Li, B. , Guan, A. , and Zhou, M. , Preparation and performances of self-compacting concrete used in the joint section between steel and concrete box girders of Edong Yangtze River Highway Bridge, Advanced Materials Research, 168-170, 2011a, 334-340.

$\mathrm{Li}, \mathrm{J}$. , Configuration of low-strength self-compacting concrete adapted to local raw materials, Advanced Materials Research, 335-336, 2011, 1159-1162.

Li, J. , Qu, X. , Chen, H. , Li, J. , and Jiang, L. , Experimental research on mechanical performance of self-compacting reinforced concrete beam with recycled coarse aggregates, Advanced Materials Research, 2012, 374-377, pp. 1887-1890.

Li, J. , Qu, X. , Wang, L. , Zhu, C. , and Li, J. , Experimental research on compressive strength of self-compacting concrete with recycled coarse aggregates, Advanced Materials Research, 306-307, 2011b, 1084-1087.

Liu, M. , Self-compacting concrete with different levels of pulverized fuel ash, Construction and Building Materials, 24, 2010, 1245-1252.

Maghsoudi, A.A. , Mohamadpour, S. , and Maghsoudi, M. , Mix design and mechanical properties of self compacting light weight concrete, International Journal of Civil Engineering, 9(3), 2011, 230-236.

Mehta, P.K. , Condensed silica fume, Concrete technology and design, in Swamy, R.N. , Cement Replacement Materials, Vol. 3, Surrey University Press, Guildford, U.K., 1986, pp. 134-170.

Mohamed, H.A. , Effect of fly ash and silica fume on compressive strength of self-compacting concrete under different curing conditions, Ain Shams Engineering Journal, 2, 2011, 79-86.

Mohamed, M.A.S. , Ghorbel, E. , and Wardeh, G. , Valorization of micro-cellulose fibers in selfcompacting concrete, Construction and Building Materials, 24, 2010, 2473-2480.

Mohammadhassani, M. , Jumaat, M.Z. , Ashour, A. , and Jameel, M. , Failure modes and serviceability of high strength self compacting concrete deep beams, Engineering Failure Analysis, 18, 2011, 2272-2281.

Najim, K.B. and Hall, M.R. , Mechanical and dynamic properties of self-compacting crumb rubber modified concrete, Construction and Building Materials, 27, 2012, 521-530.

Narasimhulu, K. , Natural and calcined zeolites in concrete, PhD thesis, submitted to Indian Institute of Technology Madras, Chennai, India, 2007.

Neville, A.M. , Properties of Concrete, 4th ed., Longman, London, U.K., 1995.

Nepomuceno, M. , Oliveira, L., and Lopes, S.M.R. , Methodology for mix design of the mortar phase of self-compacting concrete using different mineral additions in binary blends of powders, Construction and Building Materials, 26, 2012, 317-326. 
Pandurangan, K. , Kothandaraman, S. , and Sreedaran, D. , A study on the bond strength of tension lap splices in self compacting concrete, Materials and Structures/Materiaux et Constructions, 43, 2010, 1113-1121.

Parra, C. , Valcuende, M. , and Gomez, F. , Splitting tensile strength and modulus of elasticity of self-compacting concrete, Construction and Building Materials, 25, 2011, 201-207.

Prakash, P.V.S. , Development and behavioural characteristics of silica fume concretes for aggressive environment, PhD thesis, submitted to IIT Madras, Chennai, India, May 1996.

Rahman, A. , Nondestructive tests of self-compacting concrete with compressive strength (20-80 MPa), MSc thesis, University of Mustansiriya, Baghdad, Iraq, May 2008, 108pp.

Rao, G.S.N. , Effective utilization of fly ash in concretes for aggressive environment, PhD thesis, submitted to IIT Madras, Chennai, India, May 1996.

Roy, D.M. , Silsbee, M.R. , Sabol, S. , and Scheetz, B.E. , Superior microstructure of highperformance concrete for long-term durability, Transportation Research Record, 1478, 1995, 11-19.

Sahmaran, M. , Christianto, H.A. , and Yaman, I.O. , The effect of chemical admixtures and mineral additives on the properties of self-compacting mortars, Cement and Concrete Composites, 28, 2006, 432-440.

Scheetz, B.E. , Silsbee, M.R. , and Roy, D.M. , Fundamental aspects of the durability of cementitious waste forms, in Proceedings of the Indo-US Workshop on Durability of Concrete Structures, Indian Concrete Institute, Bangalore, India, 1993.

Sebaibi, N. et al. , Composition of self-compacting concrete (SCC) using the compressible packing model, the Chinese method and the European standard, Construction Building Materials, 43, 2013, 382-388.

Sellevold, E.J. and Radjy, F.F. , Condensed silica fume (Micro silica) in concrete: Water demand and strength development, First CANMET/ACI International Conference, SP-79, Malhotra, V.M. (Ed.), ACI SP 79, Vol. II, 1983, pp. 677-694.

Smith, I.A. , The design of fly ash concretes, in Proceedings of the Institution of Civil Engineers, London, U.K., Vol. 36, 1967, pp. 769-790.

Sree Rama Kumar, V. , Behaviour of GGBS in concrete Composites, MS thesis, submitted to Indian Institute of Technology Madras, Chennai, India, 1999.

Su, N. , Hsu, K.C. , and Chai, H.W. , A simple mix design method for self compacting concrete, Cement and Concrete Research, 31, 2001, 1799-1807.

Sua-lam, G. and Makul, N. , The use of residual rice husk ash from thermal power plant as cement replacement material in producing self-compacting concrete, Advanced Materials Research, 415-417, 2012, 1490-1495.

Sukumar, B. , Nagamani, K. , and Raghavan, R.S. , Evaluation of strength at early ages of selfcompacting concrete with high volume fly ash, Construction and Building Materials, 22, 2008, 1394-1401.

Surekha, S. , Performance of rice husk ash concretes, MS thesis, submitted to Indian Institute of Technology Madras, Chennai, India, 2005.

Tayeb, B. , Abdelbaki, B. , Madani, B. , and Mohamed, L. , Effect of marble powder on the properties of self-compacting sand concrete, The Open Construction and Building Technology Journal, 5, 2011, 25-29.

Tittarelli, F. and Moriconi, G. , Use of GRP industrial by-products in cement based composites, Cement and Concrete Composites, 32, 2010, 219-225.

Turk, K. , Caliskan, S. , and Yazicioglu, S. , Capillary water absorption of self-compacting concrete under different curing conditions, Indian Journal of Engineering and Materials Sciences, 14, 2007, 365-372.

Turk, K. , Turgut, P. , Karatas, M. , and Benli, A. , Mechanical properties of self-compacting concrete with silica fume/fly ash, in Ninth International Congress on Advances in Civil Engineering, 27-30, 2010, 1-7.

Valcuende, M. and Parra, C. , Bond behaviour of reinforcement in self-compacting concretes, Construction and Building Materials, 23, 2009, 162-170.

Vejmelkova, E. , Keppert, M. , Grzeszczyk, S. , Skalinski, B. , and Cerny, R. , Properties of selfcompacting concrete mixtures containing metakaolin and blast furnace slag, Construction and Building Materials, 25, 2011, 1325-1331.

Vilanova, A. , Fernandez-Gomez, J. , and Landsberger, G.A. , Evaluation of the mechanical properties of self compacting concrete using current estimating models: Estimating the modulus 
of elasticity, tensile strength, and modulus of rupture of self compacting concrete, Construction and Building Materials, 25, 2011, 3417-3426.

Walraven, J. , Self-compacting concrete: Development and applications, in Proceedings of Fib (CEB-FIP) Workshop, Chennai, India, November 2003.

Zhao, H. , Sun, W. , Wu, X. , and Gao, B. , Effect of initial water-curing period and curing condition on the properties of self-compacting concrete, Materials and Design, 35, 2012, 194-200.

\section{Performance and Service Life of Self-Compacting Concrete}

AASHTO T277, Standard Method of Test for Rapid Determination of the Chloride Permeability of Concrete (AASHTO T277), American Association of State Highway and Transportation Officials, Washington, DC, 1983.

Anagnostopoulos, N. , Sideris, K.K. , and Georgiadis, A. , Mechanical characteristics of selfcompacting concretes with different filler materials, exposed to elevated temperatures, Materials and Structures, 42, 2009, 1393-1405.

Assie, S. , Escadeillas, G. , and Marchese, G. , Durability of self compacting concrete, in Third International, RILEM Symposium, Reykjavik, Iceland, 2003, pp. 655-662.

ASTM C1202, Standard Test Method for Electrical Indication of Concrete's Ability to Resist Chloride Ion Penetration, ASTM Standards, West Conshohocken, PA, 1994.

Atan, M.N. and Awang, H. , The mechanical properties of self-compacting concrete incorporating raw rice husk ash, European Journal of Scientific Research, 60(1), 2011, 166-176.

Barrita, C.F.D.J. , Bremner, T.W. , and Balcom, B.J. , Effects of curing temperature on moisture distribution, drying and water absorption in self-compacting concrete, Magazine of Concrete Research, 55, 2003, 517-524.

Boström, L. , Self-compacting concrete exposed to fire, in Third RILEM Symposium on SelfCompacting Concrete, Reykjavik, Iceland, 2003, pp. 863-869.

Boulekbache, B. , Hamrat, M. , Chemrouk, M. , and Amziane, S. , Flowability of fibre-reinforced concrete and its effect on the mechanical properties of the material, Construction and Building Materials, 24, 2010, 1664-1671.

Brouwers, H.J.H. and Radix, H.J. , Self-compacting concrete: Theoretical and experimental study, Cement and Concrete Research, 35, 2005, 2116-2136.

Browne, R.D. and Baker, A.P. , The performance of structural concrete in marine environment, in Developments in Concrete Technology, Lydon, F.D. (ed.), Applied Science Publishers, London, U.K., 1979, pp. 111-149.

CEB , Diagnosis and assessment of concrete structures-State-of-art report, Bulletin No. 192, Comité Euro-International du Béton (CEB), Lausanne, Switzerland, 1989, p. 120.

CEB-FIP , Durable Concrete Structures: Design Guide, Thomas Thelford, London, U.K., 1992, p. 128.

CEB-FIP Model Code , Committee Euro-International du Beton, Thomas Telford, London, U.K., 1994.

Chi, J.M. , Huang, R. , and Yang, C.C. , Effects of carbonation on mechanical properties and durability of concrete using accelerated testing method, Journal of Marine Science and Technology, 10, 2002, pp. 14-20.

Craeye, B. , De Schutter, G. , Wacquier, W. , Van Humbeeck, H. , Van Cotthem, A. , and Areias, L. , Closure of the concrete supercontainer in hot cell under thermal load, Nuclear Engineering and Design, 241, 2011, 1352-1359.

De Schutter, G. , Audenaert, K. , Boel, V. , Vandewalle, L. , Dupont, D. , Heirman, G. , Vantomme, J. , and Hemricourt, D. , Transport properties in self compacting concrete and relation with durability: Over view of a Belgium Research Project, in Self-Compacting Concrete, Third International, RILEM Symposium, Reykjavik, Iceland, 2003, pp. 799-807.

El-Dieb, A.S. , Mechanical, durability and microstructural characteristics of ultra-high-strength self-compacting concrete incorporating steel fibers, Materials and Design, 30, 2009,

4286-4292. 
Fares, H. , Remond, S. , Noumowe, A. , and Cousture, A. , High temperature behaviour of selfconsolidating concrete, Microstructure and physicochemical properties, Cement and Concrete Research, 40, 2010, 488-496.

Florida DOT , An accelerated laboratory method for corrosion testing of reinforced concrete using impressed current, Research report 206, Florida Department of Transportation,

Tallahassee, FL, 1978, p. 10.

Fontana, M.G. , Corrosion Engineering, 3rd edn., McGraw-Hill Book Company, New York, 1987.

Ganesh Babu, K. , Raju, P.V.S.N. , and Ranga Raju, U. , Evaluation of reinforcement corrosion in concrete under marine environment, in Proceedings of the International Conference on Offshore Mechanics and Arctic Engineering, Houston, TX, 1990.

Gesoglu, M. , Guneyisi, E. , and Ozbay, E. , Properties of self-compacting concretes made with binary, ternary, and quaternary cementitious blends of fly ash, blast furnace slag, and silica fume, Construction and Building Materials, 23, 2009, 1847-1854.

Gjorv, O.E. and Vennesland, O. , Sea salts and alkalinity of concrete, American Concrete Institute Journal, 73(9), 1976, 512-516.

Gjorv, O.E. , Vennesland, O. , and El-Budsaidy, A.H.S. , Electrical resistivity of concrete in oceans, in Proceedings of the Offshore Technology Conference, OTC paper No. 2803, Houston, TX, 1977, pp. 581-588.

Ioani, A. , Domsa, J. , Mircea, C. , and Szilagyi, H. , Durability requirements in self-compacting concrete mix design, in Concrete Repair, Rehabilitation and Retrofitting II-Proceedings of the Second International Conference on Concrete Repair, Rehabilitation and Retrofitting, Cape Town, South Africa, 2009.

Jalal, M. , Mansouri, E. , Sharifipour, M. , and Pouladkhan, A.R. , Mechanical, rheological, durability and microstructural properties of high performance self-compacting concrete containing SiO2 micro and nanoparticles, Materials and Design, 34, 2012, 389-400.

Khatib, J.M. , Performance of self-compacting concrete containing fly ash, Construction and Building Materials, 22, 2008, 1963-1971.

Kou, S.C. and Poon, C.S. , Properties of self-compacting concrete prepared with recycled glass aggregate, Cement and Concrete Composites, 31, 2009, 107-113.

Leemann, A. , Lura, P. , and Loser, R. , Shrinkage and creep of SCC-The influence of paste volume and binder composition, Construction and Building Materials, 25, 2011, 2283-2289.

Li, B. , Guan, A. , and Zhou, M. , Preparation and performances of self-compacting concrete used in the joint section between steel and concrete box girders of Edong Yangtze River Highway Bridge, Advanced Materials Research, 168-170, 2011, 334-340.

Ludwig, H.-M. , Ehrlich, N. , Hemrich, W. , and Weise, F., Selbstverdichtender beton-Grundlagen und Praxis (Self-compacting concrete-Principles and practice), Betonwerk und Fertigteil-Technik/Concrete Precasting Plant and Technology, 67(6), 2001, 58-67; 76-80.

Maage, M. , Poulsen, E. , Vennesland, $\varnothing$. , and Carlsen, J.E. , Service life model for concrete structures exposed to marine environment initiation period, LIGHTCON Report No. 2.4, STF70 A94082 SINTEF, Trondheim, Norway, 1995.

Mc Carter, W.J. and Curran, P.N. , The electrical response characteristics of setting cement paste, Magazine of Concrete Research, 36, 1984, 42-49.

Mehta, P.K. and Gjorv, O.E. , A new test for sulphate resistance of concrete, Journal of Testing and Evaluation (JTEVA), 2(6), 1974, 510-514.

Mnahoncakova, E. , Pavlikova, M. , Grzeszczyk, S. , Rovnanikova, P. , and Cerny, R. , Hydric, thermal and mechanical properties of self-compacting concrete containing different fillers, Construction and Building Materials, 22(7), 2008, 1594-1600.

Nehdi, M. , Pardhan, M. , and Koshowski, S. , Durability of self-consolidating concrete incorporating high-volume replacement composite cements, Cement and Concrete Research, 34, 2004, 2103-2112.

Persson, B. , Internal frost resistance and salt frost scaling of self-compacting concrete, Cement and Concrete Research, 33(3), 2003, 373-379.

Raju, P.V.S.N. , Corrosion behaviour of steel in concrete, PhD thesis, Indian Institute of Technology Madras, Chennai, India, 1990, p. 331.

Raghavan, K.P. , Sivarama Sarma, B. , and Chattopadhyay, D. , Creep, shrinkage and chloride permeability properties of self-consolidating concrete, in First North American Conference on the Design and Use of Self-Consolidating Concrete, ACBM, North Western University, Chicago, IL, 2002, pp. 341-348. 
Rougeau, P. , Maillard, J.L. , and Marry-Dippe, C. , Comparative study on properties of selfcompacting concrete and high performance concrete used in precast construction, in First International RILEM Symposium on Self-Compacting Concrete, Skarendahl, A. and Petersson, Ö . (eds.), Stockholm, Sweden, 1999, pp. 251-262.

Roziere, E. , Granger, S. , Turcry, Ph. , and Loukili, A. , Influence of paste volume on shrinkage cracking and fracture properties of self-compacting concrete, Cement and Concrete Composites, 29(8), 2007, 626-636.

Schiessl, P. , Corrosion of steel in concrete, Report of the Technical Committee 60-CSC RILEM, Chapman and Hall, London, 1988.

Shalon, R. and Raphael, M. , Influence of sea water on corrosion of reinforcement, ACI Journal, 55, June 1959, 1251-1268.

Siad, H. , Mesbah, H.A. , Khelafi, H. , Kamali-Bernard, S. , and Mouli, M. , Effect of mineral admixture on resistance to sulphuric and hydrochloric acid attacks in selfcompacting concrete, Canadian Journal of Civil Engineering, 37(3), 2010, 441-449.

Stark, D. , Performance of Concrete in Sulfate Environments, Portland Cement Association, Skokie, IL, 2002.

Stratfull, R.E. , Half-cell potentials and corrosion of steel in concrete, Highway Research Record, No. 433, 1973, p. 12.

Tragardh, J. and Kalinowski, M. , Investigation of the conditions for a thaumasite form of sulfate attack in SCC with limestone filler, in Third RILEM Symposium on Self-Compacting Concrete, Reykjavik, Iceland, 2003, pp. 844-854.

Tumidajski, P.J. , Chan, G.W. , Feldman, R.F. , and Strathdee, G. , A Boltzmann-Matano analysis of chloride diffusion, Cement and Concrete Research, 25(7), 1995, 1556-1566.

Turk, K. , Caliskan, S. , and Yazicioglu, S. , Capillary water absorption of self-compacting concrete under different curing conditions, Indian Journal of Engineering and Materials Sciences, 14, 2007, 365-372.

Uysal, M. and Sumer, M. , Performance of self-compacting concrete containing different mineral admixtures, Construction and Building Materials, 25(11), 2011a, 4112-4120.

Uysal, M. and Tanyildizi, H. , Predicting the core compressive strength of self-compacting concrete (SCC) mixtures with mineral additives using artificial neural network, Construction and Building Materials, 25(11), 2011b, 4105-4111.

Vejmelkova, E. , Keppert, M. , Grzeszczyk, S. , Skalinski, B. , and Cerny, R. , Properties of selfcompacting concrete mixtures containing metakaolin and blast furnace slag, Construction and Building Materials, 25, 2011, 1325-1331.

Whitting, D. , Insitu measurement of the permeability of concrete to chloride ions, Special Publication of ACI, SP-82, American Concrete Institute, Detroit, MI, 1983, pp. 501-524. Whiting, D. , In situ measurements of the permeability of concrete to chloride ions, in ACI SP82, American Concrete Institute, Farmington Hills, MI, 1984, pp. 501-524.

Zhao, H. , Sun, W. , Wu, X. , and Gao, B. , Effect of initial water-curing period and curing condition on the properties of self-compacting concrete, Materials and Design, 35, 2012, 194-200.

Zhu, W. and Bartos, P.J.M. , Permeation properties of self-compacting concrete, Cement and Concrete Research, 33(6), 2003, 921-926.

\section{Frontiers and Research Needs}

El-Dieb, A.S. , Mechanical, durability and microstructural characteristics of ultra-high-strength self-compacting concrete incorporating steel fibers, Materials \& Design, 30, 2009, 4286-4292. Okamura, H. , Maekawa, K. , and Mishima, T. , Performance based design for self-compacting structural high-strength concrete, in Seventh International Symposium on the Utilization of HighStrength/High-Performance Concrete, Washington, DC, ACI SP 228, 2005, pp. 13-34. Park, S.H. , Kim, D.J. , Ryu, G.S. , and Koh, K.T. , Tensile behaviour of ultra-high performance hybrid fibre reinforced concrete, Cement and Concrete Composites, 34, 2012, 172-184. Richard, P. and Cheyrezy, M. , Composition of reactive powder concretes, Cement and Concrete Research, 25(7), 1995, 1501-1511. 
Rossi, P. , Influence of fiber geometry and matrix maturity on the mechanical performance of ultra-high-performance cement-based composites, Cement and Concrete Composites, 37, 2013, 246-248. 